Illinois State University

ISU ReD: Research and eData

Theses and Dissertations

6-6-2016

\title{
A Vision of Peace Through U.S. Leadership: President Jimmy Carter's Moral Foreign Policy Vision and the Panama Canal Treaties
}

Holly L. Welsh de Paula

Illinois State University, hwdepau@ilstu.edu

Follow this and additional works at: https://ir.library.illinoisstate.edu/etd

Part of the International Relations Commons, Peace and Conflict Studies Commons, and the United States History Commons

\section{Recommended Citation}

Welsh de Paula, Holly L., "A Vision of Peace Through U.S. Leadership: President Jimmy Carter's Moral Foreign Policy Vision and the Panama Canal Treaties" (2016). Theses and Dissertations. 605.

https://ir.library.illinoisstate.edu/etd/605

This Thesis is brought to you for free and open access by ISU ReD: Research and eData. It has been accepted for inclusion in Theses and Dissertations by an authorized administrator of ISU ReD: Research and eData. For more information, please contact ISUReD@ilstu.edu. 


\title{
A VISION OF PEACE THROUGH U.S. LEADERSHIP: PRESIDENT JIMMY CARTER'S MORAL FOREIGN POLICY VISION AND THE PANAMA CANAL TREATIES
}

\author{
Holly L. Welsh
}

\section{Pages}

This thesis examines President Jimmy Carter's foreign policy and his administration's campaign to promote the ratification of the Panama Canal treaties from 1977 to 1978. I argue that President Carter's administration developed a coherent foreign policy vision that was inspired by moral convictions and aimed to promote international peace. The fundamental aspects of this vision are reflected in the Panama Canal treaties. During the turbulent Senate debate over the treaties, opposition arguments attacking President Carter's moral policy encouraged the Carter administration to favor more pragmatic arguments in support of the treaties, which ultimately obscured President Carter's overarching foreign policy vision. This study demonstrates how the efforts of a single president can significantly change the direction of American foreign policy, yet also reveals the tentative nature of such changes.

KEYWORDS: Foreign Policy, Jimmy Carter, Panama Canal Treaties 


\section{A VISION OF PEACE THROUGH U.S. LEADERSHIP: PRESIDENT JIMMY CARTER'S MORAL FOREIGN POLICY VISION AND THE PANAMA CANAL TREATIES}

HOLLY L. WELSH

A Thesis Submitted in Partial Fulfillment of the Requirements for the Degree of

MASTER OF SCIENCE

Department of History

ILLINOIS STATE UNIVERSITY 
(C) 2016 Holly L. Welsh 


\section{A VISION OF PEACE THROUGH U.S. LEADERSHIP: PRESIDENT JIMMY CARTER'S MORAL FOREIGN POLICY VISION AND THE PANAMA CANAL TREATIES}

HOLLY L. WELSH

COMMITTEE MEMBERS:

Patrice E. Olsen, Chair

Ross A. Kennedy 


\section{ACKNOWLEDGMENTS}

Thank you to all of the people who have encouraged my academic pursuits, especially my friends, family, and teachers. I appreciate your support. I would especially like to thank my thesis committee for your time and advice. Thank you to my thoughtful and encouraging advisor, Dr. Patrice Olsen, who has worked with me patiently for many

years. Finally, I would especially like to thank Jacob Lusk, who motivates me daily to follow through and put forth my best effort in everything I do.

H. L. W. 


\section{CONTENTS}

Page

ACKNOWLEDGMENTS

CONTENTS

ii

\section{CHAPTER}

I. INTRODUCTION 1

II. DEFINING A VISION: PRESIDENT JIMMY CARTER'S

FOREIGN POLICY

Morality and History 16

Democratic Ideals $\quad 19$

Honesty and Transparency $\quad 24$

Respect for Sovereignty $\quad 30$

Human Rights $\quad 32$

International Cooperation and U.S. Leadership 39

$\begin{array}{ll}\text { Promoting Peace } & 47\end{array}$

III. REFLECTING A VISION: THE PANAMA CANAL TREATIES 52

Historical Inspiration $\quad 52$

Democratic Ideals $\quad 58$

Honesty and Transparency $\quad 63$

Respect for Sovereignty $\quad 65$

Human Rights 66

International Cooperation and U.S. Leadership 68

$\begin{array}{ll}\text { Promoting Peace } & 73\end{array}$

IV. OBSCURING A VISION: THE TREATY DEBATE 76

Historical Inspiration $\quad 77$

$\begin{array}{ll}\text { Democratic Ideals } & 80\end{array}$

Honesty and Transparency $\quad 84$

The Question of Sovereignty $\quad 86$

The Human Rights Contradiction $\quad 89$

International Relations and U.S. Security 93 
V. CONCLUSION

BIBLIOGRAPHY

102 


\section{CHAPTER I}

\section{INTRODUCTION}

President Jimmy Carter has recognized the Panama Canal treaties as one of his greatest accomplishments, but also identified the campaign for Senate ratification of these treaties as the greatest challenge he faced during his presidency. The two treaties were signed on September 7, 1977 and ratified by a single vote margin after months of fierce debate in the spring of 1978 . The Neutrality Treaty established permanent neutrality of the waterway, guaranteed American vessels priority passage through the canal during potential emergencies, and gave the United States the indefinite right to defend the canal from external threats. The second treaty, often referred to as the Panama Canal Treaty, scheduled the transfer of the canal from U.S. to Panamanian control after, December 31, 1999. As one of President Carter's first foreign policy initiatives, the treaties provide insight into President Carter's foreign policy vision. Historians often characterize the foreign policy of the Carter administration as moralistic and focused on human rights. What were the foundations of Carter's foreign policy vision and just how was this vision reflected in the Panama Canal treaties? ${ }^{1}$

Historians have long recognized the distinctly moral character of President Carter's foreign policy objectives. While the exact foundations of individual morality are difficult to describe, scholars have identified some of the factors that inspired President

\footnotetext{
${ }^{1}$ Jimmy Carter, White House Diary (New York: Farrar, Straus, and Giroux, 2010), 30.
} 
Carter's moralistic foreign policy. Historian Gaddis Smith argues that President Carter's position as a Washington outsider heightened his concern for morality.

Coming into Washington as the former governor of Georgia made Carter more critical of the foreign policy decisions previous presidents had made. Carter planned to restore morality into national politics. Gaddis Smith also credits President Carter's religious beliefs for inspiring his moral foreign policy agenda. Although, he does not take on the task of identifying precisely what President Carter's foreign policy vision included; instead Smith describes how President Carter's foreign policy changed over time. Such an emphasis on change may suggest a lack of any overarching vision, or perhaps the failure to communicate and achieve such a vision. ${ }^{2}$

Likewise, historians who have focused on the Panama Canal treaties as a specific policy initiative have not connected it to President Carter's moral foreign policy, which sought to emphasize human rights. David Skidmore, while conceding that Carter demonstrated "surprisingly sophisticated political skills," argues Carter's motivation for pursing the Panama treaties was largely pragmatic rather than moral. Skidmore emphasized Carter's national security interests related to the Canal treaties, without noting that the promotion of peace is often both pragmatic and moral. Historians such as Adam Clymer have detailed how the Panama Canal treaties encouraged the rise of the ultra-conservative "New Right," led by Ronald Reagan. However, Clymer does not specifically address how treaty opponents were able to gain political momentum while also undermining the foreign policy vision of the Carter administration. He focuses

\footnotetext{
${ }^{2}$ Gaddis Smith, Morality, Reason, Power: American Diplomacy in the Carter Years (New York: Hill and Wang, 1986), 27.
} 
specifically on the opposition rather than examining Carter's promotion of the Panama Canal treaties. Studying the rhetoric used within the debate over the treaties demonstrates that treaty opponents were able to effectively counter the arguments President Carter made in support of the treaties. Yet another view of the treaty is presented by Walter LaFeber, who framed the treaty debate as a historical crisis and concluded the United States was economically motivated to settle the canal dispute with Panama in an effort to develop stronger and more profitable trade relations with all of Latin America. While President Carter did discuss the mutual economic benefits derived from the treaties, economics were not the president's primary concern. He was more focused on the treaties representing a new direction for U.S. foreign policy and doing what was morally right. ${ }^{3}$

There seems to be historical consensus that Carter's foreign policy was ultimately unsuccessful. The most common criticism made about this policy is that it lacked coherence. Historian Daniel Sargent argued that the Carter administration did not recognize the limitations of human rights policy. He conceded however that Carter's interest in promoting human rights and responding to an increasingly integrated world was "a significant and constructive agenda." Sociologist and Carter biographer Kenneth Morris argued that the president's commitment to democratic and transparent decisionmaking was simply a processes lacking an end goal. He concluded, "Carter set the stage for failing in his key objective: rekindling a national faith, by definition, requires an articulation of the final hope." However, just because a policy fails, does not necessarily

\footnotetext{
${ }^{3}$ David Skidmore, "Foreign Policy Interest Groups and Presidential Power: Jimmy Carter and the Battle Over Ratification of the Panama Canal Treaties," Presidential Studies Quarterly 23, no. 3 (Summer 1993): 478.; Adam Clymer, Drawing the Line at the Big Ditch: The Panama Canal Treaties and the Rise of the Right (Lawrence, KS: U. Press of Kansas, 2008).; Walter LaFeber, The Panama Canal: The Crisis in Historical Perspective (New York: Oxford University Press, 1978).
} 
mean it was incoherent to begin with. President Carter certainly had a final hope: to promote world peace. $^{4}$

Kenneth Morris was also critical of the Carter administration, arguing that it sought to an address a "litany of discrete issues" which "cohered around no central theme and unveiled no vision of what the nation might become." This thesis demonstrates that one of Carter's first foreign policy initiatives - the negotiation of the Panama Canal treaties - did in fact embody a clear vision. Gaddis Smith notes that Carter's foreign policy reflects a time when "a fundamental debate about how the United States should behave in international affairs was waged with unusual clarity.” Certainly Carter's foreign policy reflects different principles and values than the those of his predecessors which so often reflected Cold War concerns. Careful consideration of Carter's foreign policy rhetoric demonstrates that President Carter's fundamental foreign policy goals were originally quite clear. President Carter aimed for the U.S. to take on a leadership role within a peaceful and cooperative international system. ${ }^{5}$

Historiographical considerations are difficult when studying an even as recent as the Panama Canal treaty debate. Many of the people who have documented this history were somehow involved in the negotiations, which presents a unique historical challenge. George D. Moffett, for instance, served as the Director of Research for the Committee of Americans for the Canal Treaties. William J. Jordan, author of the detailed narrative history entitled The Panama Odyssey, served as ambassador to Panama. Cyrus Vance

${ }^{4}$ Daniel Sargent, A Super Power Transformed: The Remaking of American Foreign Policy in the 1970s (New York: Oxford University Press, 2015), 11.; Kenneth E. Morris, Jimmy Carter: American Moralist (Athens, GA: U. of Georgia Press, 1996), 223.

${ }^{5}$ Morris, Jimmy Carter, 223.; Smith, Morality, Reason, and Power, 3. 
also had personal experience in Panama. When he worked as Secretary of the Army, President Johnson instructed him to go to Panama to help restore order and improve relations in the wake of the 1964 riots. Robert Pastor also served as a National Security Council staffer and as the Director of Latin American Affairs for the Carter administration. He has written extensively about American foreign policy in Latin America and often uses his own personal recollections of events rather than documents as sources. Certainly all of these people, in an effort to serve the president, had a vested interest in treaty ratification. Carefully scrutinizing their historical interpretations is all the more important due to their personal interest in the topic being studied.

Jimmy Carter's concern for human rights is a topic of much interest to historians. Human right are widely viewed as a fundamental component of Carter's foreign policy. Morris notes how President Carter sought to "link foreign policy to racial equality," by equating the American commitment to civil rights with the need to also commit to global human rights. Professor of politics Robert Strong expands on this idea. He explains how President Carter's personal experience living in the South and witnessing an end to segregation encouraged him to strive for equality and understand the potential for dramatic social change. While some scholars recognized that President Carter was unique in developing moral foreign policy, Strong noted that many of Carter's policies were simply continuations of past efforts. Strong explains that Carter's lack of foreign policy experience encouraged him to adopt policies of his predecessors, including Presidents Nixon and Ford. The Panama treaties are one example of an inherited initiative that the Carter administration enthusiastically adopted because the issue aligned so closely with President Carter's foreign policy vision. Evaluating the Panama Canal treaties helps to 
further elucidate President Carter's moralistic foreign policy motives and provide insights into his foreign policy vision. ${ }^{6}$

In regard to human rights, political scientist Kathryn Sikkink does not characterize Jimmy Carter's policy as a failure. In fact, she argues that since Carter's presidency, "human rights issues, long seen as moral concerns inappropriate for foreign policy, have become an integral part of U.S. policy and of international and regional institutions." Sikkink notes that President Carter's foreign policy contrasted sharply with the Cold War, anticommunist, policy of his predecessors. His foreign policy vision was certainly unique and produced positive results in Latin America, although as Sikkink points out, Carter's human rights policy sent "mixed signals," to the leaders and people of Latin American nations. In contrast to Sikkink's positive assessment, Joe Renourad's recent study of human rights foreign policy concludes that Carter's human rights policy, and multilateral efforts in particular were "largely unsuccessful," and even argues that the Panama Canal treaties got in the way of Carter pursuing ratification of human rights covenants. President Carter had to prioritize his public policies. Choosing to pursue the ratification of the Panama Canal treaties rather than the human rights covenants, may suggest that the treaties were more closely aligned with his ideals. The fact that the Panama Canal treaties were the first issue the Carter administration sought to tackle is indicative of their importance. ${ }^{7}$

\footnotetext{
${ }^{6}$ Robert A. Strong, Working in the World: Jimmy Carter and the Making of American Foreign Policy, (Baton Rouge: Louisiana State University, 2000) 13.; Kenneth E. Morris, Jimmy Carter: American Moralist (Athens, GA: University of Georgia Press, 1996), 263-4.

${ }^{7}$ Kathryn Sikkink, Mixed Signals: U.S. Human Rights Policy and Latin America (Ithaca, NY: Cornell University Press, 2004): 208.; Joe Renouard, Human Rights in American Foreign Policy: From the 1960s to the Soviet Collapse, (Philadelphia, PA: University of Pennsylvania Press, 2016): 165.
} 
When outlining why the Carter administration decided to pursue the Panama Canal treaties as one of its first foreign policy initiatives, historians including Gaddis Smith have recognized as the administration did, that the issue was key to relations with all of Latin America. Kenneth Morris explains that President Carter had a strong desire to internationalize foreign policy, shifting away from Cold War policy to expand U.S. engagement with the rest of the world. Negotiating new treaties with Panama allowed President Carter to demonstrate his broad international interests. Morris also recognized that the Carter administration could not have accurately anticipated the extreme congressional opposition the Panama Canal treaties generated. Perhaps this is the case, as President Carter certainly believed the issue was a bipartisan one. After all, four previous administrations had worked to reach a new agreement with Panama. Nonetheless, President Carter was aware of the congressional opposition that President Ford faced when he had pursued negotiations with Panama. Thirty-two senators, led by Republican Strom Thurmond of South Carolina, had even signed a resolution in opposition to new treaties in March of 1974. The Panama Canal continued to be a contentious topic during the 1976 Republican primaries when Ronald Reagan challenged Republican incumbent President Ford for the party's presidential nomination. President Carter knew he would face strong opposition to the treaties, but he certainly underestimated just how much opposition he would have to overcome. Despite obstacles, President Carter committed his administration to pursuing negotiation and ratification of the canal treaties. Morris rightly concluded that "to at least some extent Carter purposely picked the fight over the canal in order to dramatize his new philosophy of foreign policy.” The canal issue was an 
absolutely vital issue in Latin American relations and certainly reflected a new U.S. foreign policy approach. ${ }^{8}$

It is hard to identify the nadir of relations between the United States and Latin America in the twentieth century. The U.S. certainly had a long history of involvement in the region, dating back to before Teddy Roosevelt built the Panama Canal and pursued "Big Stick" diplomacy throughout the region. William Howard Taft's subsequent "Dollar Diplomacy" used economic loans to less overtly influence Latin American regimes. President Carter's predecessors had failed to improve relations between the U.S. and Latin American countries. Historians note that the Kennedy and Johnson administrations were at the very least guilt of ignoring Latin America, focusing their attention on the Soviet Union. The Nixon and Ford administrations, in collaboration with their Secretary of State Henry Kissinger, paid all too much attention to potential communist threats within the region. Fear encouraged the pursuit of containment policy in Latin America, which encouraged United States covert action to inspire regime change and influence policy. Such actions often encouraged or even brought to power oppressive military dictatorships.

The negotiation of new Panama Canal treaties was exceedingly controversial. Robert Pastor summarized President Carter's perspective of this “watershed event," stating that Carter "recognized that the protection of U.S. interest in an open, efficient canal required a change in U.S. strategy and a new partnership based on respect rather than a relationship of dominance based on power." Not only did President Carter believe

\footnotetext{
${ }^{8}$ Morris, Jimmy Carter, 264.; "32 Senators Back Resolution Opposing Panama Canal Pact," New York Times, Mar 30, 1974, 3.; Strong, Working in the World, 73.
} 
new treaties were imperative, he believed the relationship that existed between the U.S. and Panama needed to be repaired. He envisioned the U.S. taking on a leadership role within an international system that reflected American moral and democratic principles. ${ }^{9}$

Historians disagree as to whether the successful ratification of the Panama Canal treaties resulted in the outcomes the Carter administration had predicted and to what degree the treaties should be considered a success. Laurence Shoup sharply criticized this foreign policy initiative, arguing that it did not go far enough to improve the unequal relationship between the U.S. and Panama. According to Shoup, the treaties replaced an imperialistic relationship with a neocolonial one that would continue to influence Panama politically and economically, "backed by threat of force." Such an assessment does not reflect the reality that the Panama treaties embodied the moral and political values President Carter deemed essential. The final new agreement with Panama did not produce immediate dramatic results, seeing as the canal was not turned over from the U.S. to Panama until 1999. The treaties still reflected President Carter's morally inspired foreign policy. Gaddis Smith argued the Panama treaties did not produce positive outcomes throughout Latin America or for the Carter administration politically. Carter was not specifically concerned about these consequences. He supported the Panama Canal treaties because he believed it was the right thing to do. While he hoped the treaties would have positive effects throughout Latin America, his concern about his political future was limited. Michael Hogan's research supports my conclusion that President

\footnotetext{
${ }^{9}$ Robert A. Pastor, Exiting the Whirlpool: U.S. Foreign Policy toward Latin American and the Caribbean. (Boulder, CO: Westview Press, 2001), 12.
} 
Carter's respect for American democratic and moral ideals encouraged him to prioritize the Panama Canal treaties. ${ }^{10}$

Ultimately, President Carter chose to pursue new canal treaties "with enthusiasm," because they embodied his moral and political values. President Carter's foreign policy philosophy is often characterized as "liberal internationalism." This ideology emphasizes American moral values, diplomacy, and the promotion of international human rights to maintain security. While historians have examined President Carter's foreign policy, there has been little detailed analysis of whether individual foreign policy issues reflect a coherent foreign policy vision. What did President Carter aim to achieve through his foreign policy? Studying the Panama Canal treaties demonstrates that his administration did develop a clear, yet complex, foreign policy vision, embodied within the Panama Canal treaty issue. Not only was his vision coherent, it also represented a dramatic departure from the Cold War policies of the past, especially when considering relations with the developing world and Latin America. ${ }^{11}$

While historians have described the characteristics of President Carter's foreign policy in more general terms, they have not analyzed how the Panama Canal treaties specifically reflect President Carter's foreign policy vision. What were the foundational beliefs that inspired Carter to fight for ratification of the treaties so ardently? It seems that historians have underestimated the extent that President Carter sought to emphasize

\footnotetext{
${ }^{10}$ Laurence Shoup, Carter Presidency and Beyond, (Palo Alto, CA: Ramparts Press, 1980): 140.; Smith, Morality, Reason, and Power, 132.; J. Michael Hogan, The Panama Canal in American Politics: Domestic Advocacy and the Evolution of Policy, (Carbondale, IL: Southern Illinois University Press, 1861): 3.

${ }^{11}$ Morris, Jimmy Carter, 263-4; George D. Moffett III, The Limits of Victory: The Ratification of the Panama Canal Treaties, (Ithaca, NY: Cornell University Press, 1985), 20, Moffett discusses the fundamental ideas associated with liberal internationalism.
} 
America's moral leadership through the negotiation and ratification of the Panama Canal treaties. The Panama Canal treaties not only helped to correct what the Carter administration characterized as a historical injustice, but Carter also hoped to set a new precedent for the conduct of American foreign policy. The U.S. would promote international peace and justice through its diplomatic efforts.

When considering the case of the Panama Canal treaties, it is clear that moral concerns motivated President Carter's foreign. His vision of international relations demanded America's moral democratic leadership, which required honesty and transparency in government, respect for the sovereignty of other countries, the promotion of human rights, and international cooperation in order to create a just and peaceful international system. The president believed peace could be reached through diplomatic efforts and made maintaining peace and security his highest priority. Carter signed the Panama Canal treaties and campaigned for their ratification in the Senate because he believed the treaties advanced his foreign policy vision. While the Panama Canal treaties are not often associated with President Carter's human rights policy, they did in fact further the protection of such rights. Ultimately however, the president's foreign policy vision did not gain public support due to the way in which the treaty debate was framed. Not only did opponents successfully obscure the President's message, but the Carter administration also failed to communicate its foreign policy vision in a clear and consistent manner during the treaty debate. The Carter administration often ignored the contradictions between ideals and political realities while treaty opponents challenged President Carter's credibility and commitment to human rights. 
This thesis suggests two arguments contrary to common historical consensus. First, the Panama Canal treaties can be viewed as a policy reflective of President Carter's moral foreign policy, and even as a policy that furthered human rights due to provisions that helped promote political self-determination, as well as economic and civil rights. Second, the treaties demonstrate that President Carter did indeed develop a coherent foreign policy vision, which he continued to work toward even after his presidency. While scholars have studied the Panama Canal treaties and noted that they changed the direction of American foreign policy, none have examined how the arguments made during the Panama Canal debate weakened the President's ability to communicate his overarching foreign policy vision. Following this introduction, this thesis is divided into three additional chapters followed by a conclusion. Chapter two outlines President Jimmy Carter's foreign policy vision based upon his speeches, diary entries, and correspondence within his cabinet. Chapter three connects the Carter administration's overarching foreign policy vision to the principles of the Panama Canal treaties. Chapter four explains how the treaty debate ultimately undermined President Carter's foreign policy vision. Finally, Chapter five concludes this study with a discussion of the historical significance and implications of President Carter's foreign policy vision and the Panama Canal treaty debate. 


\section{CHAPTER II}

\section{DEFINING A VISION: PRESIDENT JIMMY CARTER'S FOREIGN POLICY}

When he first announced his presidential candidacy, Jimmy Carter believed that the government was plagued by "an absence of executive vision and direction." Upon his election, he intended to solve this problem. Carter's experience as Governor of Georgia did not exactly provide him much foreign policy experience, thus he emphasized the experience he did have, his service on the Trilateral Trade Commission. With such scant experience though, he could not claim to have developed a coherent foreign policy vision prior to his election. By the time he was inaugurated though Carter had taken many steps toward developing a specific foreign policy framework. He collaborated with his future Secretary of State, Cyrus Vance and ordered government agencies carry out numerous studies so he could become better informed about foreign policy issues. ${ }^{12}$

In his inaugural address on January 20, 1977, President Carter described his foreign policy vision. He stressed "there can be no nobler nor more ambitious task for America to undertake on this day of a new beginning than to help shape a just and peaceful world that is truly humane." From his first day in office, President Carter's moral foreign policy goals were his highest priority. Considering its consistency and principled foundation, it seems President Carter's rhetoric appears to genuinely reflect his

${ }^{12}$ Quoted in Editorial Note, Foreign Relations of the United States, Foundations of Foreign Policy, 1977-1980 (Washington, D.C.: U.S. Government Printing Office, 2014), I: 2 (hereafter FRUS, with appropriate year, volume, and page numbers). 
beliefs, values, and goals. The president called for "nothing less than a sustained architectural effort to shape an international framework for peace within which our own ideals gradually can become a global reality." The ideals he identified as uniquely American "basic moral and philosophical principles" were the founding principles of the United States: an inalienable right to life, liberty, and the pursuit of happiness. Cyrus Vance spoke about "harnessing the basic values of the Founding Fathers to our foreign policy," and noted that "historically, our country has been a force for progress in human affairs." In addition to individual rights, Jimmy Carter believed the fundamental principles of American government included democracy — the idea that power is derived from the consent of the governed - as well as justice, or the rule of law, and equality, or equal protection under the law. He reveled his faith in the universality of American values when he quoted the revolutionary, Thomas Paine. Paine judged "that the cause of America is the cause of all mankind." President Carter certainly hoped to make it so. ${ }^{13}$ The president outlined his administration's foreign policy principles early in his term. His campaign rhetoric even reflected his moral principles, as did his presidential diary entries, his public addresses, and communication among the members of his cabinet. The members of President Carter's cabinet supported his vision. Historian Scott Kaufman argues that disagreement within President Carter's cabinet resulted in the pursuit of "contradictory and inconsistent policies." These disagreements however did not develop immediately after Carter took office. Even after he subsequently resigned,

\footnotetext{
${ }^{13}$ Remarks by Jimmy Carter, 15 March 1976, FRUS, 1977-1980, I: 16.; Vance, Hard Choices, 29.; Jimmy Carter, "Inaugural Address of President Jimmy Carter, January 20, 1977," in Public Papers of the President of the United States: Jimmy Carter, 1977, Book I-January 20 to June 24, 1977, (Washington, D.C.: Government Printing Office, 1977), 3 (hereafter Public Papers, with appropriate year, book, and page numbers).
} 
Secretary of State Vance reflected upon the fact that "we agreed philosophically about the main elements of a fresh approach to foreign policy." Vance, along with Vice President Walter Mondale, Defense Secretary Harold Brown, and National Security Advisor Zbigniew Brzezinski each worked toward clarifying and achieving President Carter's foreign policy vision, which was ultimately reflected in the Panama Canal treaties. $^{14}$

Carter worked closely with his cabinet members. During the early months of his presidency and throughout the treaty debate, there was cooperation and agreement within the Carter administration. It was only after the Panama Canal treaties were ratified that a "source of confusion" arose between Vance and Brzezinski. Vance explained that tensions grew because Brzezinski often assumed "the role of policy spokesman," which was a role Vance believed he should have held himself as the Secretary of State. Cyrus Vance decided to resign his position as Secretary of State in April of 1980, nearly two years after the Panama Canal treaties were ratified. During the Senate debate over the treaties the Carter administration was united in pursuing treaty ratification. Less than a month after his 1977 inauguration, Carter spoke before State Department officials and said, "I can tell you in the most accurate way that there is no disharmony. We have open, and frank discussions." Vance described relations within the cabinet as "collegial," and noted the "relative absence of interdepartmental jealousies." He respected the president, noting he was "highly intelligent and had firm principles." Vance explained that "there was broad agreement among the president and his principal advisors on the main outlines

\footnotetext{
${ }^{14}$ Scott Kaufman, Plans Unraveled: The Foreign Policy of the Carter Administration, (DeKalb, IL: Northern Illinois University Press, 2008): 4.; Vance, Hard Choices, 29.
} 
of our policy." This study therefore, considers the Carter administration and executive branch officials as a united force, working toward the same foreign policy vision and the ratification of the Panama Canal treaties. ${ }^{15}$

\section{Morality and History}

President Carter believed his administration's foreign policy decisions should be guided by basic moral principles. He also thought individual morality and national morality were inextricably linked and that nations, like individuals, should follow a specific set of moral standards. Carter promised he would not "do anything as President that would be a contravention of the moral and ethical standards that I would exemplify in my own life as an individual." Carter believed foreign policy decisions should follow the "do unto others as you would have them do unto you," - his paraphrase of Matthew 7:12. Again, this principle suggests his belief that countries, like individuals must follow a set of moral values. Instead of basing foreign policy decisions on calculations of military strength, estimations of resources or other diplomatic concerns, using the golden rule to guide foreign policy suggests Carter believed countries should be diplomatically engaged and cooperate on equal terms. ${ }^{16}$

Carter also derived many of his political values from history. The past inspired him to conclude that the American people were exceptionally capable of acting according to democratic principles. Other scholars have recognized this quality in Carter's foreign policy as well. Kenneth Morris described how Carter maintained a "populist faith in the

${ }^{15}$ Vance, Hard Choices, 37-8.; "Department of State - Remarks and a Q \& A Session with Dept. Employees," February 16, 1977, Public Papers, 1977, Book I, 236.; Vance, Hard Choices, 33,38.

${ }^{16}$ Quoted in Smith, Morality, Reason, and Power, 29.; "Interview by John Hart, NBC News," March 28, 1976, in Wesley G. Pippert ed., The Spiritual Journey of Jimmy Carter In His Own Words, (New York: MacMillan Publishing Company, 1978), 101. 
people to make the right moral decisions if only the decision-making process is an open one." Not only was Carter committed to acting according to his moral principles, he also believed unequivocally that democratic government was ideal and he sought to further democratic goals and values through his foreign policy. ${ }^{17}$

Once elected, President Carter aimed to correct past foreign policy errors. He spoke at length about the immoral foreign policy pursuits of past administrations. Vance too recognized a "progressive erosion of our countries' relations," prior to Carter's election. The president understood that recent American foreign policy had damaged the credibility of the American government and he sought to improve the international reputation of the United States. Carter was open and honest about what he believed to be errors the U.S. committed in the past. He voiced his concerns about the dishonesty of past administrations, and specifically criticized past administrations for the Watergate scandal, the Vietnam War, and ill-advised, if not criminal U.S. covert actions. He spoke of "the tragedy of American involvement in Vietnam," and one of the first actions he took as president was to pardon draft evaders. Carter sought to reform a political system he believed was previously damaged by past immoral policies. ${ }^{18}$

The President's deep religious convictions likely inspired his belief in the value of repentance. President Carter was a devout born-again Christian, and often spoke of his faith guiding him in politics. He taught Bible classes and frequently spoke of how he practiced his faith. In a speech before a Bible class in Georgia before his election, he explained, "I pray every day that I don't disappoint you or do anything that will make

\footnotetext{
${ }^{17}$ Morris, Jimmy Carter, 222.

18 Vance, Hard Choices, 19.; "Executive Order Relating to Proclamation of Pardon, Executive Order 11967," January 21, 1977, Public Papers, 1977, Book I, 6.
} 
you ashamed." He even used religious language when asked whether he believed the president was responsible for correcting errors the U.S. committed in the past. President Carter matter-of-factly stated, "obviously, if I see a sinful act or an improper or heartless act being carried out by our nation in the past or present or future, it is my responsibility as president to stop that action and to atone through action for inequities or suffering that has been caused by it." President Carter felt he had a moral obligation to not only promote just foreign policy, but to also remediate problems stemming from past immoral policies. The negotiation of the Panama Canal treaties allowed Carter to correct a policy problem of the past that he believed conflicted with U.S. values. In order to do so, the Carter administration outlined the fundamental democratic principles that the administration sought to promote. ${ }^{19}$

The president was also concerned about past unlawful covert actions carried out by U.S. intelligence agencies. Prior to serving as President Carter's Vice President, Walter Mondale served as a senator from Minnesota. In the Senate, Mondale had served on the Church Committee, which was tasked with investigating "illegal, improper, or unethical activities," carried about by the CIA or other Federal agencies. The committee issued its final critical report in April of 1976. The report demanded there be congressional oversight of intelligence activities, and made public many "illegal, improper, and unwise acts" carried out by the CIA, including assassination plots, covert operations aimed at overthrowing a democratic regime, drug testing on American citizens, domestic spying, and blackmail attempts aimed at civil right leaders. President

${ }^{19}$ Pippert, The Spiritual Journey, 45, 121.; "Remarks by Jimmy Carter," 15 March 1976, FRUS, 1977-1980, I: 23. 
Carter was well aware of all of these findings and upon taking office sought to reform the American intelligence community. ${ }^{20}$

Historical redemption was important to Carter because he sincerely wanted to improve the reputation of the U.S. He knew that past policies and preemptive efforts to curb conflict with the Soviet Union had encouraged the U.S. to enter conflicts that he viewed as immoral. Carter's cabinet supported his efforts. Vice President Walter Mondale spoke regretfully about how Americans "became absorbed in the narrower struggle against communism, and in the process supported and ultimately overcommitted ourselves to some of the most outrageously oppressive regimes in the world." The president's new foreign policy would be dramatically different from the Cold War policy of his predecessors. Carter encouraged the American public to aid his efforts to reorient American foreign policy. He recognized that the U.S. should work "to restore the historical vision of decency and honesty and truth and principle to our country." He was willing to go to great lengths to make sure that the United States followed through with this "great responsibility."21

\section{Democratic Ideals}

President Carter believed foreign policy should reflect democratic ideals and principles. He explained that despite past government errors, Americans have "got the best system of government on Earth." His commitment to democracy was unwavering. He sincerely believed that despite the large size of the federal government, it should still

20 "Introduction," Foreign and Military Intelligence, Book I, Final Report of the Select Committee to Study Governmental Operations, 26, April 1976 (Washington, D.C.: U.S. Government Printing Office, 1976), 2, 12.

21 “Statement by Senator Walter F. Mondale," June 2, 1975, FRUS, I: 53. Pastor, Exiting the Whirlpool, 40. 
be accountable to the American public. He also recognized that the Chief Executive should work collaboratively with Congress and sought to increase communication between the two branches while he was in office. Another democratic ideal President Carter valued highly was justice. Carter explained during his presidential campaign that, "one of the major responsibilities I have as a leader and as a potential leader is to try to establish justice." He believed government should encourage fairness, which he often equated with yet another democratic value: equality. ${ }^{22}$

President Carter believed the American people should be included in the democratic process. He insisted that "America's foreign policy should reflect the character of the American people." Carter thought the democratic heritage of the United States made its people uniquely moral and just. He believed that "in every foreign venture that has failed - weather it was Vietnam, Cambodia, Chile, Angola or in the excesses of the CIA—our government forged ahead without consulting the American people." In all of these instances, Carter explained that the government "did things that were contrary" to the "basic character," of the American people. The president had an unshakable faith in the public's ability to act morally. In his view, "every successful foreign policy...was successful because it reflected the best that was in us."23

Logically, President Carter also believed that his foreign policy vision had received a mandate from the people upon his election. When discussing his human rights policy he expressed his desire to act according to the public will, stating "I believe I speak accurately for the American people on this subject." Carter also sought to keep the

22 "Remarks and a Question-and-Answer Session at the Clinton Town Meeting," March 16, 1977, Public Papers, 1977, Book I, 401.

23 “Remarks by Jimmy Carter," 15 March 1976, FRUS Foundations, I: 17. 
American public informed by communicating "directly and candidly." The president published a book compilation of campaign speeches and interviews early in his presidency in an attempt to express "the personal beliefs and political themes upon which my candidacy was based." President Carter felt it was important to communicate the views that he believed the American people had endorsed when they elected him president. Despite maintaining deep consternation for past immoral policies, the Carter administration believed that when the American people were able to influence foreign policy, they would do so in a way that reflected their fundamental moral character. Carter thought past foreign policy errors were not a reflection of the will of the inherently good majority of Americans. Instead these problems developed when a lack of transparency disconnected the American public from the democratic policy-making process. ${ }^{24}$ President Carter encouraged his administration to be democratically accountable through close collaboration and frequent communication with elected officials in Congress. Carter noted that the Nixon and Ford Administrations had "seriously damaged" the "longstanding traditions of a bipartisan policy and close consultation with Congress." The president therefore sought to clarify and justify his policies to increase public and Congressional support. Secretary of State Vance met with members of Congress almost every week in an effort to explain executive policy and answer questions. Vance estimated that nearly one-fourth of his time was dedicated to legislative matters. The president too collaborated with Congressmen extensively. When drafting the Executive Order 12036 that reformed the U.S. intelligence agencies, President Carter recognized a

${ }^{24}$ Jimmy Carter: "The President's News Conference," March 9, 1977. Online by Gerhard Peters and John T. Woolley, The American Presidency Project. http://www.presidency.ucsb.edu/ws/?pid=7139.; Jimmy Carter, A Government as Good as Its People, (New York: Simon and Schuster), 7-8. 
half dozen congressmen for their efforts to help draft the order. He thanked the chairman of the Senate Intelligence Committee, Senator Birch Bayh [D-IN] and former chairman Senator Daniel Inouye [D - HI], along with the chairman of the House Committee, Edward Boland [D - MA] for "a great deal of consultation and close cooperation." Carter promoted democratic policies by consulting members of Congress about executive actions and foreign policy. ${ }^{25}$

Soon after his confirmation as Secretary of State Cyrus Vance identified four principles of "realistic American foreign policy." The first and most important was that, "foreign policy should be understood and supported by the American people and the Congress." To achieve this democratic objective, the Carter administration sought to explain their foreign policy to both the public and their representatives in Congress in an effort to generate consensus and support. To reach out to the public, the president hosted frequent televised fireside chats, attended public forums, and held press interviews. Vance described how the president was an "earnest, intelligent man who grasped the necessity of basing his leadership and policies on the support and common sense of the American people." President Carter always attempted to communicate his perspectives on policies to the American public. One example of such ardent communication, was Carter's July 1979 televised "Crisis of Confidence" speech, during which he called on the American people to make civic sacrifices in an effort to pursue American ideals. The speech was poorly received, but the fact that Carter communicated his sincere view on

25 "Remarks by Jimmy Carter," 15 March 1976, FRUS, 1977-1980, I: 16.; Vance, Hard Choices, .33.; "United States Foreign Intelligence Activities Remarks on Signing Executive Order 12036," January 24, 1978. Online by Gerhard Peters and John T. Woolley, The American Presidency Project. http://www.presidency.ucsb.edu/ws/?pid=31089. 
policy demonstrates his commitment to keeping the public informed and involved in the policy making process. Carter believed that providing information to citizens would encourage them to follow his moral example in support of his political and foreign policy goals. $^{26}$

President Carter also envisioned the United States leading the world by example, through the promotion of justice. Carter planned for the U.S. to once again promote “more decent and just relations among people and among societies." Promoting justice was also vital to the Carter administration. The president's personal religious beliefs reinforced this value. Carter once described how he prayed to be able to "do simple justice through government." When he took the oath of office, he chose a Bible passage emphasizing justice as well. His selection, Micah 6:8, reads, "what doth the Lord require of thee, but to do justly, and to love mercy, and to walk humbly with God?" Carter was clearly guided by the moral principles of justice and fairness and hoped the U.S. could help build a peaceful international system that would reflect these democratic values. ${ }^{27}$ Equality was yet another democratic value President Carter sought to pursue. He even said that "the purpose of government is to alleviate inequalities." Not only was the equality of man "self-evident" according to the Declaration of Independence, it was also an essential element within Article One of the Universal Declaration of Human Rights, which states that "all human beings are born free and equal in dignity and rights." President Carter's desire to promote equality was linked to his human rights campaign in

26 “Remarks by Jimmy Carter," 15 March 1976, FRUS, 1977-1980, I: 16.; Vance, Hard Choices, .33 .

${ }^{27}$ Carter, "Our Nation's Past and Future," in Pippert, The Spiritual Journey, 94.; Carter, Keeping Faith: Memoirs of a President (New York: Bantam Books, 1982), 20. 
both the United States and abroad. Carter even applied his vision of greater equality on the international level. Not only did the Carter administration insist on individual equality, it also believed in treating other countries equally. Regardless of size, development, or military strength, the Carter administration sought to diplomatically engage with all nations. ${ }^{28}$

President Carter valued equality because he recognized inequality threatened his ultimate goal of maintaining peace. He spoke about the growing wealth disparity between nations. "The world will not be a safe or decent place in which to live, however, if it continues to divide between countries which are increasingly rich and those which are increasingly impoverished." The Carter administration believed it was the responsibility of rich nations to provide aid to less developed countries, and support programs that would specifically help the poor and reduce inequality. ${ }^{29}$

\section{Honesty and Transparency}

For President Carter making more open and transparent foreign policy decisions was also important within a democracy. Honesty was fundamental to his presidential campaign and foreign policy vision. Before he was elected, Carter emphatically stated, "I would not lie; I would not mislead the American people; I would not avoid taking a stand on a controversial issue which is important to our country or the world. And I would not betray your trust." This commitment to honesty helped him claim the presidency, at a time when the public was widely skeptical about government credibility because of both the Vietnam War and the Watergate scandal. Carter declared that the government "must

${ }^{28}$ Carter, A Government, 93.; UN General Assembly, Universal Declaration of Human Rights, 10 December 1948, 217 A (III).

29 “Address by Jimmy Carter," 28 May 1975, FRUS, 1977-1980, I: 8. 
never again keep secret the evolution or our foreign policy from the Congress and the American people." By emphasizing his commitment to moral principles, which included honesty, Carter sought to restore the public's trust in the government. ${ }^{30}$

The president recognized that without clear and honest information the people would be excluded from the democratic process. Carter forcefully argued the United States "must move away from making policies in secret; without the knowledge and approval of the American people." He voiced disapproval of U.S. policy particularly when it involved secret negotiations. When campaigning for president, he specifically criticized Henry Kissinger's service as Secretary of State, concluding that Kissinger "simply does not trust the judgement of the American people, but constantly conducts foreign policy exclusively, personally, and in secret." Carter pledged to do the opposite in an effort to prevent further foreign policy disasters. He described how "each time our nation has made a serious mistake the American people have been excluded from the process." He went on to criticize the government for the "tragedy of Vietnam and Cambodia," "the disgrace of Watergate," and the "embarrassment of the CIA," whose assassination program was immoral and also violated human rights and international law. The president argued these mistakes "could have been avoided if our government had simply reflected the sound judgment and good common sense and the high moral character of the American people." He called for a reevaluation of past government policies, "to strip away the secrecy," so the U.S. could once again assume moral leadership within foreign policy. Carter described the importance of transparency, stating

${ }^{30}$ Pippert, The Spiritual Journey, 75.; “Address by Jimmy Carter,” 28 May 1975, FRUS, 19771980, I: 5. 
"in a democratic system like ours, foreign policy decisions must be able to stand the test of public examination and public debate." He pledged to be honest and open with American citizens in regards to foreign policy in an effort to build public trust. ${ }^{31}$

The Carter administration encouraged communication and honest discussion within the government as well. In the State Department, Secretary Vance sought to open communication between officials of varying ranks by maintaining a "dissent channel." Vance also sought to make the State Department's personnel more representative of American society, furthering the administration's effort to promote the democratic principle of equality. ${ }^{32}$

Early in his presidency, Carter sought to win the trust of the American public by reforming U.S. intelligence agencies. Carter ended payments to foreign government officials who worked as informants, include Manuel Noriega of Panama. He stated that the U.S. "must not use the CIA or other covert means to effect violent change in any government or government policy.” In a speech before the intelligence community, he reinforced his fundamental belief in honesty when he called for all clandestine service members to "be even more pure and more clean and more decent and more honest than almost any persons who serve in government." He believed this honesty was necessary due to the increased scrutiny the CIA faced after the public had learned of the illegal actions the agency carried out. ${ }^{33}$

\footnotetext{
31 "Address by Jimmy Carter," 8 September 1976, FRUS, 1977-1980, I: 42.; "Remarks by Jimmy Carter," 15 March 1976, FRUS, 1977-1980, I: 16.; Carter, ““'Our Nation's Past and Future”; Jimmy Carter, "State of the Union Address," 19 January 1978, quoted in FRUS, 1977, I: 306.

${ }^{32}$ Vance, Hard Choices, 42-3.

33 “Address by Jimmy Carter," 28 May 1975, FRUS, 1977-1980, I:4.; Central Intelligence Agency, Notes from the Director, no. 27, August 28, 1978.
} 
President Carter's criticism of the CIA assassination program demonstrated his commitment to the most fundamental of human rights: the right to life. On January 24, 1978, just four days after taking the oath of office, Carter issued the aforementioned Executive Order No. 12036, which included a prohibition on assassination. Carter explained that the order established "in clear terms the responsibilities and limitations" of the intelligence community. President Mondale called the order "historic," insisted that the U.S. could not only defend itself "within the law," but could do so better than “through illegality." Both Carter and Mondale were deeply troubled by the findings of the Church Committee and sought to reform U.S. intelligence protocol. ${ }^{34}$

By August 1978, Carter had also removed George H. W. Bush from his position as Director of the Central Intelligence Agency, and appointed Admiral Stansfield Turner to the position. Turner recognized that the CIA was "to operate within the law" because “there were ethical limits as to what President Carter would want us to do." He explained how he often consulted with the president before making difficult ethical decisions. Just months after Turner took charge of the Agency, Carter concluded that "relations between the CIA and the American public have been substantially improved." He promised the American people "there are no illegal or improper actions now being conducted," within the clandestine service. Carter recognized that transparency within the secret service was impossible, but sought to reassure the American people that the CIA was no longer breaking the law to carry out its foreign policy objectives. The president also pledged that

${ }^{34}$ Executive Order No. 12036. United States Foreign Intelligence Activities. January 24, 1978.; Central Intelligence Agency, Notes from the Director, no. 27, August 28, 1978.; "United States Foreign Intelligence Activities Remarks on Signing Executive Order 12036," January 24, 1978. Online by Gerhard Peters and John T. Woolley, The American Presidency Project. http://www.presidency.ucsb.edu/ws/?pid=31089. 
if he were to discover an "impropriety or an illegality I will not only take immediate action to correct it but also will let the American people know about it."35

Despite Carter's objections to CIA activities carried out in the past, he did believe that intelligence was vital. He recognized that "we have got to have a good intelligence system in order to protect the security of our country." Carter thought reforms were necessary within the intelligence community because "we sometimes relax too much in peacetime." The result of secret service reforms was an emphasis on proactive rather than reactive intelligence. Carter judged the CIA was "one of the best means to make sure we don't have war." He recognized the inherent contradiction that the CIA created within an ideally transparent democratic government. No matter how ardently Carter valued honesty, he would not allow his commitment to get in the way of his most fundamental goal: maintaining security and peace. ${ }^{36}$

President Carter also believed honesty was essential to reestablishing U.S. moral leadership. He believed that immoral policies had undermined the reputation of the U.S. During a 1976 presidential debate, Carter criticized his opponent stating "every time Mr. Ford speaks from a position of secrecy — in negotiation and secret treaties that have been pursued and achieved, in supporting dictatorships, in ignoring human rights — we are weak and the rest of the world knows it." He went on to specifically criticize the secret nature of past policies in Vietnam, Chile, and Rhodesia. Carter emphatically declared that

\footnotetext{
35 Tim Weiner, Legacy of Ashes, (New York: Anchor Books), 414.; Central Intelligence Agency, Notes from the Director, no. 27, August 28, 1978.; “Carter's News Conference February 23," March 21, 1977, Department of State Bulletin, LXXCI, no. 1965 (Washington, D.C.: U.S. Government Printing Office, 1977): 251.

36 Jimmy Carter, "Remarks and a Question-and-Answer Session with Department Employees," February 24, 1977, Public Papers, 1977, Book I, 243.
} 
"Americans have been shaken by tragic war abroad and by scandals and broken promises at home." He explained, "we want to have faith again. We want to be proud again. We just want the truth again." The president recognized that like the American people, other countries had lost faith and trust in the U.S government. "To be true to ourselves, we must be true to others," he stated. For his foreign policy to be effective, and allow the U.S. to assume a leadership role within the world, he sought to restore honesty and transparency to diplomacy. President Carter spoke of American morals as absolute and stressed they would not only be applied domestically, but also internationally. During his inaugural address, Carter promised that the U.S. would "not behave in foreign places so as to violate our rules and standard here at home, for we know that the trust which our Nation earns is essential to our strength." Reaffirming the value of truth and transparency was an essential aspect of President Carter's overall foreign policy vision. He wished to demonstrate to the American public and countries around the world the moral redirection of his administration's foreign policy. ${ }^{37}$

Honesty was particularly important to the Carter Administration's foreign policy vision, because the ultimate goal of this vision was for the U.S. to lead by example in an effort to promote democracy and peace. Carter recognized that inspiring other countries to follow the lead of the U.S. would require the trust of the international community. The president hoped to gain international trust by honestly following through with past promises. He pledged that the U.S. would, "always honor those commitments which have been made openly by our leaders and with full knowledge and involvement of the

${ }^{37}$ Quoted in Smith, Morality, Reason, and Power, 29, from The Presidential Campaign 1976.; Gerald R. Ford: "Presidential Campaign Debate," October 6, 1976, Public Papers of the President, 1976-77 Book III, 2414. 
people of our country." Carter believed that honest policy would repair the tarnished reputation of the U.S. ${ }^{38}$

\section{Respect for Sovereignty}

Respect for the national sovereignty of other countries was another crucial aspect of President Carter's foreign policy. For President Carter, respect for sovereignty went beyond criticizing the U.S. for engaging in unpopular foreign wars, or for carrying out covert operations that undermined democratic elections. While Carter voiced his disapproval of both of these policies, he also believed the U.S. should seek to reform its policy by demonstrating a new respect for sovereignty and not intervening in the affairs of other nations. In an address before the Organization of American States, Carter discussed his "high regard for the individuality and sovereignty of each Latin American and Caribbean nation." He promised that the United States would "not act abroad in ways that we would not tolerate at home in our own country." President Carter's respect for national sovereignty was rooted in morality and particularly in his understanding of the golden rule. ${ }^{39}$

The Carter administration also believed that respecting the sovereignty of other nations would increase the national security of the United States and promote global peace. Carter explained that the U.S. “doesn't have an inclination to be involved in the internal affairs of another country unless our security should be directly threatened." The president saw security as the only conceivable reason for the U.S. to infringe on the rights of another sovereign state. He went on to explain that the U.S. had "learned that never

38 “Address by Jimmy Carter," 28 May 1975, FRUS, 1977-1980, I:5.;

39 Organization of American States Address before the Permanent Council, April 14, 1977, FRUS, 1977-1980, I: 136. 
again should our country become militarily involved in the internal affairs of another country unless there is a direct and obvious threat to the security of the U.S. or its people." Carter committed the United States to respecting the sovereignty of other countries. $^{40}$

The president sought to improve the reputation of the United State by reiterating his respect for sovereignty. He explained that the reputation of the U.S, or "the moral heart of our international appeal — as a country which stands for self-determination and free choice— - has been weakened." Past policies that interfered with the democratic process were of particular concern to Carter. "I don't think our country has a prerogative or responsibility to determine the form of government of other people," he explained. The president again demonstrated his respect for democracy and sovereignty when he stated that despite past errors, "it is obviously un-American to interfere in the free political process of another nation." Maintaining security and peace was again the ultimate goal of a policy that promoted international cooperation. ${ }^{41}$

President Carter believed it was essential to correct past policy errors. Carter recognized that in the years before he was elected, the U.S. had "often been overextended, and deeply entangled in the internal affairs of distant nations." $\mathrm{He}$ regretted that the U.S. "pursued dubious tactics," and explained "“national security' has sometimes been a cover-up for unnecessary secrecy and national scandal.” One example of such a policy was the CIA effort to effectively negate the results of the 1973

40 "Question-and-Answer Session at a Town Meeting," 15 July 1978, Public Papers, 1978, Book2., 1303.; “Address by Jimmy Carter," 28 May 1975, FRUS, 1977-1980, I: 4.

41 "Remarks by Jimmy Carter," 15 March 1976, FRUS, 1977-1980, I: 16.; Pippert, The Spiritual Journey, 101. 
democratic election of Salvador Allende in Chile. Such interference resulted in a devastating economic crisis and catastrophic human rights abuses in Chile, under the American backed regime of Augusto Pinochet. Carter wanted to guarantee the U.S. did not repeat the foreign policy errors it had made in the past. In order to assume a leadership role in the world, the U.S. had to redeem itself for past errors, which all too often infringed upon the sovereignty of other nations. Carter sought to improve the reputation of the United States by demonstrating respect for both the sovereignty of other nations and for human rights. ${ }^{42}$

\section{Human Rights}

President Carter was a well-known champion of human rights. During his inaugural address he stressed that the U.S. "commitment to human rights must be absolute." When Carter discussed human rights he often spoke of those rights discussed in the United States government's founding documents and the Bill of Rights in particular. Carter believed the U.S. was exceptionally able to lead the world in promoting human rights because Americans had a long history of enjoying these fundamental rights. Carter claimed human rights were "the soul" of his foreign policy and went on to explain, that his emphasis on human rights was "part of a broad effort to use our great power and our tremendous influence in the service of creating a better world, a world in which human beings can live in peace, in freedom, and with their basic needs adequately met." Again, the idea of moral leadership is reflected in Carter's vision of foreign policy. President Carter recognized that human rights could be best protected during times of

\footnotetext{
${ }^{42}$ Quoted in Smith, Morality, Reason, and Power, 29; Carter, The White House Diary, 87.
} 
peace, and also interpreted human rights quite broadly to include not only political civil rights, but also the economic rights. ${ }^{43}$

The Carter administration sought to promote three different categories of human rights. Rights protecting the integrity of the person from governmental violation were of particular concern and included freedom from the most serious government violations, including "torture; cruel, inhuman or degrading treatment and punishment; arbitrary arrest or imprisonment; denial of fair public trial; and invasion of the home." In regard to such rights, the Carter administration realized developing institutions to prevent such abuses was the ultimate goal. While addressing violations against individuals was certainly important, building a system that would respect human rights would provide more benefits to greater numbers of people. ${ }^{44}$

The Carter administration defined economic rights as "an individual's efforts to fulfill his vital needs for food, shelter, health care and education.” While, political rights were seen as most directly connected to the American "heritage and basic values," and included all of the First Amendment rights Americans had long enjoyed, including, "freedom of thought, of religion, of assembly, of speech, of the press;" as well as freedom to move within and outside of a country and freedom to participate in government. The administration sought to expand political and economic rights in

43 "Universal Declaration of Human Rights Remarks at a White House Meeting Commemorating the $30^{\text {th }}$ Anniversary of the Declaration's Signing," 6 December 1987, Papers of the President, 1978, Book-II, 2163.

${ }^{44}$ Warren Christopher, “Presidential Review Memorandum on Human Rights,” July 8, 1977, State Department, 1-3. 
countries where the government's respect for the personal integrity of its citizens was already entrenched. ${ }^{45}$

Carter also sought to work collaboratively with other countries to promote human rights. He stated "you will find the U.S. eager to stand beside those nations which respect human rights and which promote democratic ideals." The Carter administration acted to promote human rights abroad by cutting of aid, especially military aid, opposing potential loans from international agencies, and making public statements about the importance of human rights and in some cases even specific instances of abuse. To confront a government guilty of serious human rights abuses, the Carter administration planned to unite the world behind its cause, and put forth effort "to bring to bear international opinion and concerted action by the world community against such a regime." Carter sought to set an international agenda and foster cooperation among nations to promote a greater respect for international human rights and broader concern about human rights abuses. $^{46}$

The Carter administration recognized they needed to maintain "a principled yet pragmatic defense of basic human rights." The need for a flexible human rights policy was undeniable, since many other political considerations had to be made simultaneously. Carter wanted the U.S. policy to be as productive as possible and realized that taking a stand against all incidents of abuse would not be realistic. President Carter understood human rights to include those same democratic rights of equality, justice, and sovereignty

${ }^{45}$ Warren Christopher, "Presidential Review Memorandum on Human Rights," July 8, 1977, State Department, 1-3.

${ }^{46}$ Pastor, Exiting the Whirlpool, 44.; "Presidential Review Memorandum on Human Rights," July 8, 1977, State Department, 22. 
previously discussed. The United Nations Universal Declaration of Human Rights specifically included these and many others in its detailed and thorough definition of human rights. The document's preamble states "the equal and inalienable rights of all members of the human family is the foundation of freedom, justice and peace in the world." President Carter hoped to emphasize the very same principles and goals discussed within this fundamental human rights document. ${ }^{47}$

President Carter promoted human rights by signing two additional human rights covenants and encouraging the Senate to ratify these measures. The International Covenant on Economic, Social and Cultural Rights, identified within its first Article that "All peoples have the right of self-determination," a right, which is inherently connected to President Carter's respect for sovereignty. Any foreign policy that does not respect the territorial integrity or government authority of another nation, violates this fundamental right. Article I also goes on to recognize that "in no case may a people be deprived of its own means of subsistence." President Carter believed that human rights included not only political civil rights, but also economic rights. The president thought that developed counties could protect the economic rights of people in developing nations by establishing mutually beneficial trade relationships. He believed the U.S. should not exploit other nations, but instead should work to improve conditions for all of humanity, elevating the ability of all people to economically sustain themselves. ${ }^{48}$

The Carter administration recognized that taking action in other countries to protect human rights could potentially infringe on the sovereignty of those countries.

\footnotetext{
${ }^{47}$ UN General Assembly, Universal Declaration of Human Rights, 10 December 1948, 217 A
} (III).

${ }^{48}$ Vance, Hard Choices, 44. 
Carter's National Security Director Brzezinski warned "conflicts in policy may arise when the security of the United States is linked to that of a country whose human rights priorities are deficient." The administration recognized political objectives needed to be prioritized and they were not willing to jeopardize U.S. national security as they pursued human rights policy. Vance recognized the necessity of being "flexible and pragmatic in dealing with specific cases that might affect our national security." Ultimately, the Carter administration recognized that taking action to curb human rights abuses needed to be done on a case by case basis. The president asked Deputy Secretary of State Warren Christopher to chair an interagency committee aimed at ensuring human rights policy was integrated into the administration's foreign policy. ${ }^{49}$

President Carter also demonstrated his commitment to human rights through his appointment of Patricia M. Derian as his Assistant Secretary of State for Human Rights. Derian explained that U.S. human rights policy was guided by three basic principles, first American efforts were global, not narrowly focused on the Soviet Union as past foreign policy as a whole had been. Second, the Carter administration sought to "consider the unique political, social, cultural, and historical realities of different countries," before developing appropriate tactics to help foster a greater respect for human rights. Lastly, human rights were one dimension of a foreign policy that also aimed to promote "national security, trade, and arms control." These multifaceted interests made human rights policy particularly difficult to implement consistently. ${ }^{50}$

49 "Remarks by Jimmy Carter," 15 March 1976, FRUS, 1977-1980, I: 105.; Pastor 46.; Vance, Hard Choices, 33.

${ }^{50}$ Patricia Derian, "Human Rights: A World Perspective," October 16, 1978, Department of State: Current Policy, 42 (Washington, D.C.: U.S. Government Printing Office, November, 1978) 2. 
The Carter administration sought to advance the cause of human rights using a variety of tactics, including public statements, particularly "when quiet diplomacy fails." Carter also sought to implement legislation promoting human rights, curb military sales to countries guilty of human rights abuses, and cut off economic aid. Patricia Derian firmly connected the administration's pursuit of international human rights and the reputation of the U.S. She believed the pursuit of moral ideals, including the protection of human rights, strengthened American "position and influence in the world." During a meeting with members of the European Human Rights Commission, Derian noted the effects of American human rights policy, stating "they strongly support it, and believe that through this policy the United States has regained much of the prestige it lost in recent years because of the pursuit of unwise policies elsewhere." Promoting human rights was a genuine moral concern of President Carter, but he also felt such a policy would strengthen the reputation of the U.S. in the world. ${ }^{51}$

The President sought to promote human rights by setting a positive example and helping to construct an international system in which human rights abuses were less likely to occur. The president sought to improve human rights conditions in countries by offering development assistance to countries that made efforts to protect these rights. President Carter's Directive 30, No. 4 stated that "countries with a good or substantially improving record of human rights observance will be given special consideration in the allocation of U.S. foreign assistance.” The Carter administration successfully supported

${ }^{51}$ Patricia Derian, "Human Rights: A World Perspective," October 16, 1978, Department of State: Current Policy, 42 (Washington, D.C.: U.S. Government Printing Office, November, 1978) 3. 
congressional action to cut off aid to Argentina in 1978 when the government was committing egregious human rights violations. ${ }^{52}$

This endeavor was successful due to the hard work and diligence of Patricia Derian, who travelled repeatedly to Argentina in 1977 and demanded policy change from both the U.S. and Argentine governments. Derian stressed the U.S. commitment to human rights and advised the president to demand the military, C.I.A. and F.B.I. all support the human rights policy of the State Department. She vocally criticized the Argentine government for "the systematic use of torture, summary execution of political dissidents, the disappearance and the imprisonment of thousands of individuals without charge... and the failure of the government of Argentina to fulfill its commitment to allow [a] visit by the Inter American Commission on human rights." Her efforts to end human rights abuses in Argentina demonstrated her personal moral principles as well as the Carter administration's vehement commitment to human rights. ${ }^{53}$

The Carter administration recognized that the global protection of human rights would not come about immediately. National Security Chief Brzezinski noted that the U.S. was "part of a political and historical process," to promote human rights. In addition to Argentina, the Carter administration's policy made a positive difference in Chile and

\footnotetext{
${ }^{52}$ Memorandum From the Assistant Secretary of State for Human Rights and Humanitarian Affairs (Derian) to the Senior Deputy Assistant of State for Economic and Business Affairs (Hormats), November 21, 1978. FRUS, 1977-1980, II: 545.; Human Rights Watch, Argentina, Dec. 2001, vol. 13, 5 "The Role of the United States," https://www.hrw.org/reports/2001/argentina/argen1201-11.htm

53 "The Pentagon and CAI Sent Mixed Message to the Argentine Military, Document 1 - Notes from U.S. State Department Human Rights Coordinator Patricia Derian," Early April 1977, National Security Archive, March 28, 2003.; "The Pentagon and CAI Sent Mixed Message to the Argentine Military, Document 8 - Testimony of Assistant Secretary Derian before the Subcommittee on Inter American Affairs, Committee on International Relations, House of Representatives," August 9, 1978, National Security Archive, March 28, 2003.
} 
Uruguay. Regretfully, the administration failed to implement its human rights policy consistently over time. While its early efforts most clearly reflect President Carter's vision, later policy, especially after the Soviet invasion of Afghanistan reflected the same concern about communism identifiable in the policies of his predecessors. ${ }^{54}$

\section{International Cooperation and U.S. Leadership}

President Carter's firm belief in the moral correctness of his foreign policy also led him to believe that the U.S. should provide moral leadership through its foreign policy. To do so Carter sought repentance for the nation's past errors in order to build confidence in the moral righteousness of his policies. In his inaugural address, Carter declared, "we must once again have faith in our country — and in one another... Let our recent mistakes bring a resurgent commitment to the basic principles of our Nation, for we know that if we despise our own government we have no future." Carter believed that just as individuals can repent for past transgressions, so too can nations. Carter was open and honest about what he believed to be errors the U.S. committed in the past, because he believed in the value of repentance and sought to reform a political system he believed had been damaged by immoral policies of the past. ${ }^{55}$

President Carter also sought to shift his foreign policy away from the anticommunist policy of containment. He believed past policy focused too exclusively on Soviet-U.S. relations. Even prior to his election, Carter envisioned collaborating closely with American allies and engaging in diplomacy to promote peace. Carter complained that in the past the "government has been so obsessed with balance of power politics that

\footnotetext{
${ }^{54}$ Quoted in "Editorial Note," 6 December 1978, FRUS, 1977-1980, II: 555.

55 Jimmy Carter "Inaugural Address," Papers of the President, 1977 I, 2.
} 
it often ignored basic American values and a proper and common concern for human rights." Carter's administration favored a more inclusive global approach. It aimed "to strive for multilateral agreements and solutions to critical problems." The president believed "ties of friendship and cooperation with our friends and neighbors must be strengthened," in order to take steps toward addressing problems that could affect all countries of the world. ${ }^{56}$

The Carter administration recognized that globalization was dramatically changing the international system, and believed the U.S. could no longer neglect the developing world. Not since the Kennedy administration had a president and his foreign policy advisors paid close attention to promoting progress in the developing world. While America's containment policy at times drew attention to less developed countries, this attention was often an effort to maintain a favorable balance of power vis-a-vis the Soviet Union. Secretary of State Vance criticized past U.S. policy for "not understanding the explosive forces of change in the developing world." The Carter administration recognized economic insecurity and human rights violations throughout the world presented a threat to global peace. Vance explained that the "future was inextricably entwined with the economic and political developments of a turbulent Third World." To address this reality, the Carter administration set goals within many parts of the developing world. When listing their most pressing foreign policy issues, Vance identified the Middle East, East Asia, southern Africa, China, and Panama specifically. The Carter administration sought to leave behind narrowly focused foreign

${ }^{56}$ Pastor, Exiting the Whirlpool, 41. 
policy focused only on the Soviet Union. Carter envisioned a global approach to foreign policy that was less centered on U.S.-Soviet relations. ${ }^{57}$

When reflecting on the U.S. desire to assume a leadership role in the world, Cyrus Vance mentioned that the administration "agreed that our allies were hoping we would provide clear and consistent American leadership." Carter also felt the U.S. was especially prepared to take on a leadership role within the international community due to the county's "reservoir of strength — economic strength, which we are willing to share; military strength, which we hope never to use again; and the strength of ideals, which are determined fully to maintain the backbone of our own foreign policy.” President Carter believed the United States to have an exceptional mission to promote international collaboration and maintain peace while also demonstrating the value of the democratic principles embodied in the U.S. Declaration of Independence, reflected in the United Nations Charter and identified in the Universal Declaration of Human Rights. ${ }^{58}$

The Carter administration planned to implement mutually beneficial foreign policy. Carter hoped common international problems could be solved through collaboration with other nations. He pointed out that "the intensity of our interrelated problems is rapidly increasing, and better mechanisms for consultation must be established and utilized before these problems become more dangerous." Carter recognized scarce energy resources, growing inequality, and environmental degradation to be some of the problems that not only affected the entire world, but required a global response to solve. The president and his Secretary of State both agreed that U.S. "allies

\footnotetext{
${ }^{57}$ Cyrus Vance, Hard Choices, 23, 27.

${ }^{58}$ Cyrus Vance, Hard Choices, 32.; “Address by Jimmy Carter Before the United Nations General Assembly," 17, March 1977, FRUS, 1977-1980, I: 109.
} 
were hoping we would provide clear and consistent American leadership," and "felt confident that for the first time in years, the United States was politically, psychologically, and materially capable of offering leadership." The Carter administration believed it was an international necessity for the U.S. to assume a leadership role. ${ }^{59}$

President Carter wanted to reestablish a cooperative relationship with Latin American countries specifically. Speaking to the Permanent Council of the Organization of American States in Washington, just months after his inauguration, Carter said "the challenge we face is to awake our institutions to a changing world. We must focus our attention on the problems which face our countries and tailor each solution to its problem." Carter favored diplomacy and international collaboration to resolve problems in an increasingly integrated world. He admitted, "my heart and my interest to a major degree is in Latin America." The president even spoke some Spanish; although he also joked in Spanish that he would, "follow the advice of my friends, who have the opinion that, in the interest of good relations, it would be best not to speak Spanish today." Carter hoped to "strengthen the ties of friendship and a sense of common purpose and close consultation with the nations and the peoples of the Caribbean and Latin America," For President Carter, international collaboration could potentially benefit all nations and was an essential step toward achieving a peaceful international system. ${ }^{60}$

Carter also believed that taking on a leadership role in the world required the U.S. to take an active role within international organizations, including the United Nations

\footnotetext{
${ }^{59}$ FRUS, 5.; Vance, Hard Choices, 32.

60 "Address by President Carter Before the Permanent Council of the Organization of American States," 14, April 1977, FRUS, 1977-1980, I: 141.; Pastor, Exiting the Whirlpool, 40.
} 
(UN) and Organization of American States (OAS). When addressing the international community, Carter hoped to "underline his fundamental support for the institutions of the United Nations, for multilateral international cooperation." Carter spoke reverently of the United Nations as a "house where the shared hopes of the world can find a voice." When speaking at the OAS, Carter stressed "a need for constant cooperation, consultation, and harmony among nations," and identified a new agreement with Panama as a step toward such cooperation. ${ }^{61}$

In addition to working within the OAS, President Carter also sought to correct past policy errors made in Latin America. Secretary Vance believed the U.S. "should forge a sounder, more equal relationship with Latin America." The Panama Canal treaties sought to do just that. The Carter administration identified past American policies as problematic and pledged to work with developing nations in a more respectful and mutually beneficial way. President Carter and his foreign policy advisors noted how previous administrations had either ignored relations with Latin America, or damaged them through their foreign policy. Carter hoped "to reduce misunderstanding and promote good relationships among people and groups in the region." Vance recognized that upon taking office, the Carter administration was "faced with the consequences of our long neglect and the residue of resentment stemming from past paternalism," throughout Latin America. The Carter administration believed past actions and policies in Latin America had damaged the reputation of the United States which would impair the country's ability to serve as a world leader and promote peace. ${ }^{62}$

61 "Statement by the Deputy Secretary of State (Christopher) Before the Senate Foreign Relations Committee Subcommittee on Foreign Assistance," 7, March 1977, FRUS, 1977-1980, I: 107-8, 134.

${ }^{62}$ Vance, Hard Choices, 33, 444; Pastor, Exiting the Whirlpool, 55. 
While President Carter internationalized U.S. foreign policy, he did not neglect U.S.-Soviet relations. He planned to continue implementing the policy of détente, which Vance described as an easing of tensions. The president recognized that this policy "was not easy to define or to defend to the American public." Despite this challenge, President Carter hoped to reduce tensions between the U.S. and Soviet Union in order to fulfill his ultimate goal of promoting world peace. To further his policy, the Carter administration put great effort into the second round of Strategic Arms Limitations Talks (SALT II) with the Soviet Union. The agreement that resulted from these talks certainly reflected the Carter administration's policy vision and desire to promote peace, but Carter recognized that the treaties did not have the necessary Senate support to be ratified. In fact, the president recalled that some Republican leaders who voted to ratify the Panama Canal treaties, including Senator Howard Baker [R-TN], stated that "they would never support SALT II, no matter what was in it." Scholars have noted that the President used considerable political capital on the Panama treaties. The president was willing to do this because the treaties aligned so closely with his foreign policy vision. President Carter continued to lobby for public support of SALT II, but eventually withdrew the agreement from congressional consideration after the Soviet Union invaded Afghanistan in 1979. ${ }^{63}$

Carter believed the U.S. should lead the world in creating an international system that valued international cooperation. To do so, Carter knew the United States needed to exercise restraint and engage in diplomacy rather than use military force. In his inaugural address, Carter described his commitment to restraint, explaining "the powerful must not

\footnotetext{
${ }^{63}$ Vance, Hard Choices, 22.; Jimmy Carter, interview by Charles O. Jones et al, Carter Presidency Project, November 29, 1982, 57.
} 
persecute the weak." This notion harkened back to Franklin Roosevelt's 1943 Christmas radio address, during which Roosevelt claimed "the doctrine that the strong shall dominate the weak is the doctrine of our enemies — and we reject it." President Carter's foreign policy principles had both spiritual and historical foundations. Religion inspired President desire for the U.S. to take on a leadership role in the world. The president cited Micah 4:3 as the foundation for his belief that powerful countries should lead rather than exploit weaker nations. The passage states, "and He shall judge among many people, and rebuke strong nations afar off; and they shall beat their swords into plowshares, and their spears into pruninghooks: nation shall not lift up a sword against nation, neither shall they learn war any more." Carter indeed sought to deemphasize the military strength of the U.S. and inspire global change through moral leadership. Carter conceded in his inaugural address that "we do not seek to intimidate" other countries regarding their human rights policies. He described his plan to "maintain strength so sufficient that it need not be proven in combat - a quiet strength based not merely on the size of an arsenal but on nobility of ideas." Carter hoped U.S. moral leadership would bring about international cooperation. His faith in the righteousness of his ideals and the values of the American nation likely bolstered his confidence. ${ }^{64}$

Despite recognizing the strength of the United States, the Carter administration also realized that independently working towards peace was not as constructive as encouraging collaboration and mediating conflicts. Carter knew that alone "the United States cannot solve the problems of the world." He spoke of past policy errors and the

${ }^{64}$ Franklin Roosevelt quoted in Mary Ann Glendon's A World Made New: Eleanor Roosevelt and the Universal Declaration of Human Rights, (New York: Random House, 2001): 4.; Jimmy Carter: "Inaugural Address," Public Papers, 1997, Book I, 3. 
damaged reputation of the U.S., stating "the good will our country once enjoyed, based on what we stood for and the willingness of others to follow our example, has been dissipated." The Carter administration wanted to use international organizations to repair the reputation of the United States and once again set an example of moral and democratic leadership in the world. ${ }^{65}$

The Carter administration sought to earn international respect by following through with past commitments. Vice President Mondale recognized that "all the military might in the world does not enable us to command the respect we once had in the international arena." The administration also recognized the importance of domestic policy, when attempting to assume an international leadership role. "World leadership and respect will be determined by how well we meet the needs of our people - for only in that way can this nation recapture its unique claim to being the last, best hope for mankind.” The Vice President expressed his high expectations for the leadership potential of the United States government. He also refused to let the tumultuous foreign policy conflicts of the Cold War inspire isolationist policies, pledging that the U.S. was "not opting out of the world." Instead, he agreed with President Carter's view that the United States should be "leading the way toward economic progress and social justice and a stronger, more stable international order." The Carter administration believed U.S. leadership was an essential aspect of a foreign policy vision aimed at creating a just and peaceful world. ${ }^{66}$

${ }^{65}$ Address by President Carter Before the United Nations General Assembly, March 17, 1977 , FRUS, 1977-1080, I: 16.

${ }^{66}$ Statement by Vice President Walter F. Mondale, Washington, June 2, 1975, FRUS, 1977-1980, I: 13-15.; Remarks by Jimmy Carter, March 15, 1976, FRUS, 1977-1980, I: 17. 
The president listed the many ways in which the U.S. was prepared to promote peace, democracy, and justice. Carter called on Americans to "remember that because of our tremendous and continuing economic, military, and political strength, the United States has an inevitable role of leadership to play within the community of nations." President Carter believed that the U.S. and other developed countries had a special responsibility to improve the world. He was proud to lead the world in advocating for human rights as well. Carter planned for the U.S. to take on a "leadership role and let the world say that the focal point for the preservation and protection of human rights is in the United States of America." ${ }^{97}$

\section{Promoting Peace}

President Carter rightly admitted that his administration had "broad aspirations." Vance noted that the president preferred "a bold 'comprehensive' approach rather than a more modest 'incremental,' building on past agreements. Like the United Nations, the president's highest priority was the maintenance of peace. Not only did the president believe it was his responsibility to guarantee national security, but he also pledged that the U.S. would "be tenacious and determined in our search for a greater world peace." Carter explained that American "interests lie in protecting our national security, in preventing war, in peacefully promoting the principles of human freedom and democracy, and in exemplifying in our foreign policy the true attitudes and character of the American people." President Carter's ultimate goal was to maintain peace, and he

${ }^{67}$ Address by Jimmy Carter, May 28, 1975, FRUS, 1977-1980, I: 8; Jimmy Carter, "The President's New Conference of March 9, 1977," in Papers of the President, 1977, Book I, 341. 
believed the best way to do this was for the U.S. to set an example for other countries throughout the world by pursing just foreign policy. ${ }^{68}$

President Carter argued that no matter how important maintaining national security was, this interest should not be used to rationalize immoral foreign policy. Vice President Walter Mondale argued that "the fog of national security helped to lead us into the tragic swamp of Vietnam, into the morass called Watergate." The Carter administration recognized national security had been used as a justification for past immoral policies. President Carter felt that the U.S. should avoid military entanglements at all costs and sought to do so by pursing diplomatic efforts to resolve conflicts. Vice President Mondale also criticized the past militarization of American foreign policy. He argued that such narrow policy made the United States "virtually helpless when confronted by major international economic problems, such as energy." The Carter administration acknowledged that new global problems would require collaborative solutions instead of costly military endeavors. The administration wanted to broaden foreign policy in an effort to work constructively with other nations to solve problems that could potentially threaten international peace. ${ }^{69}$

President Carter also sought to promote peace by advocating for a reduction in arms sales internationally. The Carter administration sought to curb the U.S. private sale of arms throughout the world and encouraged other developed countries to do so as well. Cyrus Vance promised a Soviet delegation at a meeting in Moscow just months after the

${ }^{68}$ Vance, Hard Choices, 31, 4.; “Carter's News Conference February 23,” March 21, 1977, Department of State Bulletin, LXXCI, no. 1965 (Washington, D.C.: U.S. Government Printing Office, 1977): 260.; Address by Jimmy Carter, May 28, 1975, FRUS, 1977-1980, I: 4.

${ }^{69}$ Statement by Vice President Walter F. Mondale, Washington, June 2, 1975, FRUS, 1977-1980, I: 10 . 
president was inaugurated, that the U.S. planned "to make a serious effort to restrain and reduce this trade." The Carter administration promised that "the United States would show restraint in its own arms sale," and aimed to bring about a more peaceful and less violent world through the control of both conventional and nuclear arms. ${ }^{70}$

President Carter celebrated the promotion of peace within other regions as well, including Latin America. His administration hoped "to work with all nations to halt the spread of nuclear explosive capabilities," and he commended Latin American nations for signing the 1967 Treaty of Tlatelolco, which declared Latin America a nuclear-weapon free zone. Carter pledged the U.S. would not move nuclear weapons into Latin America when he signed Protocol I of this treaty on May 26, 1977, demonstrating yet again his personal commitment to nonproliferation. ${ }^{71}$

Secretary of State Vance also strongly believed in the pursuit of peace. In his memoirs he noted that President Kennedy's belief that peace is the "necessary rational end of rational men," also reflected his own personal views. Vance concluded that there was "no more urgent task," than the pursuit of peace. He thought that peace would evolve gradually through "a series of concrete actions and effective agreements." The Panama Canal treaties were one example of policy the administration pursued in pursuit of peace. $^{72}$

President Carter demonstrated his goal of promoting peace went beyond maintaining the security of the U.S. when he mediated talks between Egyptian President

${ }^{70}$ Memorandum of a Conversation, March 28, 1977, FRUS, 1977-1980, I: 128.

${ }^{71}$ Address by President Carter Before the Permanent Council of the Organization of American States, April 14, 1977, FRUS, 1977-1980, I: 137.; Pastor, Exiting the Whirlpool, 44.

${ }^{72}$ Vance, Hard Choices, 20. 
Anwar el-Sadat and Israeli Prime Minister Menachem Begin at Camp David in September of 1978. The Camp David Accords were developed during twelve days of talks and aimed to end three decades of conflict between Egypt and Israel. President Sadat spoke highly of Carter's "determination to purse what is right," and recognized that the "paramount commitment" of the American president was "to the cause of peace and the universal brotherhood of man." For their efforts to come to an agreement, Sadat and Begin were awarded the Nobel Peace Prize in 1978 and went on to sign a finalized peace agreement based upon the Camp David Accords in March of 1979. President Carter's commitment to peace was an overarching goal that extended beyond the borders of the United States. $^{73}$

Ultimately, the president sought to help create an international system that would promote American ideals and establish a lasting global peace. He spoke of this vision in his inaugural address stating that in the years following his presidency "I would hope that the nations of the world might say that we had built a lasting peace, based not on weapons of war but on international policies which reflect our own most precious values." Again, Carter's message reflects his ultimate goal and his belief in the unique strength of American values. President Carter certainly counted human rights among those values as well as American democratic principles. He argued "we know the best way to enhance the freedom in other lands is to demonstrate here that our democratic system is worthy of emulation." Carter strove to set a positive example through American

73 "Toasts of the President and President Sadat at a Dinner Honoring the Egyptian President," April 4, 1977, Papers of the President, 1977, Book I, 568. 
action. One of the first actions he took as president was to pursue negotiation and ratification of new Panama Canal treaties. ${ }^{74}$

${ }^{74}$ Jimmy Carter "Inaugural Address," Papers of the President, 1977 I, 3. 


\section{CHAPTER III:}

\section{REFLECTING A VISION: THE PANAMA CANAL TREATIES}

The moral nature of President Carter's foreign policy is evident when considering many of the foreign policy issues he pursued, including the SALT II negotiations and the Camp David Accords. Like these more obvious examples of Carter's morally inspired foreign policy, the Panama Canal treaties were also meant to advance President Carter's overarching foreign policy vision. When the Panama Canal treaties became a divisive political issue, the Carter administration chose to lead an intense political battle to get the treaties ratified. The administration recognized they were key to establishing new and productive relationships among the U.S. and Latin American countries. The treaties also helped the U.S. to repair its international reputation and gain credibility. Examining the struggle for ratification of the Panama Canal treaties provides great insights into both the President Carter's foreign policy principles and his administration's foreign policy vision. Why did President Carter believe the Panama Canal treaty reflected his moral foreign policy vision? To answer that question, it is essential to study the president's understanding of the Panama Canal's history.

\section{Historical Inspiration}

President Carter recalled he was originally prompted to study the Panama Canal treaty issue in greater detail during his campaign for president in 1975 when thirty-eight senators sponsored a resolution never to change the original Panama Canal Treaty signed in 1903. Carter read a great deal about the history of the canal's construction and began 
to question the traditional celebratory history of the canal. Like many Americans and historians, President Carter had a difficult time reconciling the great success of the canal's construction with the diplomatic duplicity involved in securing the rights to construct it. The president sought to explain this history to the American people to justify new canal treaties. He described the United States' role in Panama achieving its independence, but also identified the original 1903 canal treaty between the U.S. and Panama as one of the "problems that plague us from the past." Carter lamented both the way in which the original treaty had been negotiated as well as the fairness of the treaty provisions. The Carter administration sought to negotiate and ratify new treaties to address the major points of contention between the U.S. and Panama. ${ }^{75}$

At the turn of the $20^{\text {th }}$ Century, Panama was a Colombian province. That all changed in 1903, when the U.S. backed Panamanian independence from Colombia, by moving the U.S. Navy into Colon Harbor after a Panamanian revolt. Such a show of force allowed for a successful and bloodless revolution to take place in Panama. After recognizing Panamanian independence, the U.S. used its position of power to bargain for the right to build a canal across the Isthmus of Panama. U.S. officials negotiated a treaty with Philippe Bunau-Varilla, a Frenchman, who was appointed Ambassador Extraordinary and Minister Plenipotentiary by Panamanian leaders. Bunau-Varilla had encouraged the Panamanian revolt, hoping to negotiate a canal agreement with the United States. The U.S., had long been interested in constructing a Central American canal and had originally signed a treaty with Colombia for canal rights in 1846. Bunau-Varilla had

${ }^{75}$ Organization of American States Address before the Permanent Council, April 14, 1977, FRUS, 1977-1980, I: 138. 
a financial stake in the construction of a canal across Panama. He had invested in the 1879-1888 French effort to construct a sea level canal, and after that endeavor failed, he sought out to negotiate a canal treaty between the U.S. and Panama to recoup some of his losses. Acting on Panama's behalf, Bunau-Varilla travelled to the U.S. and signed a treaty offering very generous terms to the United States, before the Panamanian delegation even arrived in Washington to join the negotiations. Panamanians objected to the treaty immediately, but believed their very independence rested upon the treaty's ratification. One of President Carter's primary objection to the original treaty was that "no Panamanian ever saw the treaty at all before it was signed." Panamanians began protesting the terms of this treaty immediately although they could not do so freely fearing that without U.S. military support, Colombia could try to force Panama to once again have a provincial status. In the decades before President Carter's election Panamanians consistently demanded revisions to the original canal agreement. ${ }^{76}$ In 1903, with the U.S. now guaranteeing Panamanian independence, the Panamanian Senate ratified the Hay Bunau-Varilla Treaty. The agreement granted the U.S a 10 mile wide strip of land through which the U.S. would lead an effort to construct a canal connecting the Atlantic and Pacific Oceans. This "Canal Zone" effectively divided the new republic in two and also became a barrier to free movement of Panamanians within their own country. The treaty also offered. "all rights, power and authority.....which the United States would possess and exercise as if it were the sovereign of the territory." While Panama technically retained legal sovereignty over its territory, the U.S. acted "as if it were the sovereign" of the territory. The U.S. imposed tariffs on

\footnotetext{
${ }^{76}$ Carter, White House Diary, 30.; Carter, White House Diary, 86.
} 
the importation of goods into the Canal Zone, claimed legal jurisdiction, ran its own mail system, used U.S. currency, and controlled the air space above the Zone. In addition to objecting to the sovereignty clause, Panamanians also objected to the term of the treaty, which stated it would be in effect "in perpetuity." The treaty's inequitable terms would endure unless a new treaty was negotiated. President Carter saw renegotiation as a necessity. He did not believe the original treaty accurately reflect the values and character of the American people.

President Carter describe the original Panama Canal Treaty as "obviously unfair." He cited U.S. Secretary of State John Hay's 1903 assessment of the treaty to support this claim. Hay described the treaty terms as "vastly advantageous to the United States and...not so advantageous to Panama." The Carter administration planned to negotiate new treaties that would align with the President's moral foreign policy vision. Upon taking office, Carter's desire to pursue a new canal treaty reflected his sense of historical justice. The treaty that allowed the U.S. to construct the Panama Canal "cheated the Panamanians out of their canal," according to President Carter. Carter felt the new Panama Canal treaties were necessary to correct the "injustice," of the 1903 Hay-BunauVarilla Treaty. ${ }^{77}$

President Carter's interest in redeeming the U.S. for past policy errors increased his interest in the Panama Canal issue. He studied the topic at length, learning that the U.S. had settled the dispute over Panamanian independence with Colombia in 1921 with

${ }^{77}$ Carter, The White House Diary, 30.; Jimmy Carter, "Address to the Nation on the Panama Canal Treaties," February 1, 1978, American Presidency Project, http://www.presidency.ucsb.edu/ws/?pid=29995 (hereafter $A P P$ ).; Carter, The White House, 86. Jimmy Carter, White House Diary (New York: Farrar, Straus, and Giroux, 2010) 30. 
the Thomson-Urritia Treaty. The U.S. support for Panamanian independence and the subsequent construction of the Panama Canal violated this earlier treaty. To compensate Colombia, the U.S. agreed to pay $\$ 25$ million dollars for the canal rights it had acquired from Panama. Panama however received very few economic benefits after the canal was constructed. The U.S. did share any profits collected from the operation of the canal. The Thomson-Urritia treaty did however acknowledge the legitimacy of Panamanian independence, which meant after 1921, Panamanians could increasingly advocate for a fairer canal arrangement. Panama no longer had to worry that Colombia would try to reclaim Panamanian territory.

Panama objected to the economic arrangements the 1903 treaty had established. The country did not receive a share of any of the tolls collected from ships that used the waterway. The tariffs imposed on trade within the Canal Zone, made relations between the U.S. and Panama even more strained. One estimate suggested that the U.S. benefited four or five to one from trade with Panama. ${ }^{78}$

In 1931, Panamanian protests and Franklin D. Roosevelt’s “Good Neighbor," policy inspired the U.S. to offer additional canal profits to Panama. However, this agreement, did not solve the two primary Panamanian objections: the U.S. infringing on Panamanian sovereignty in the Canal Zone and perpetuity of the original 1903 treaty. Panamanians also argued that the U.S. kept Canal tolls artificially low.

Despite the dubious negotiations involved in reaching the 1903 canal agreement, President Carter refused to shy away from the mainstream notion that the construction of the canal was an unprecedented historical achievement. He said that "building the canal

${ }^{78}$ Farnsworth and McKenney, U.S. Panama Relations, 24. 
was one of the greatest engineering feats of history." Despite his objections to the original canal treaty, the agreement did make way for the successful construction of the Panama Canal. U.S. effort to construct the canal took over a decade and cost the lives of an estimated 5,600 workers. Carter encouraged Americans to feel "justly and deeply proud of this great achievement." Perhaps such patriotic rhetoric was meant to balance the president's complaints about the original treaty. What is evident is that the Carter administration did not let sentimentality about the canal's construction hinder their efforts to negotiate a new and more just agreement. ${ }^{79}$

The Carter administration followed through with negotiations of two new treaties that would solve the two primary objections Panamanians had to the 1903 treaty. Rather than enduring for perpetuity, like the original treaty was intended to, the new Panama Canal Treaty would turn over control of the canal to Panama on a set date: December 31, 1999. The treaty also outlined the steps that would be taken toward this transition in the interim period. The Canal would be controlled by a new U.S. Government agency, the Panama Canal Commission, which would initially have a board of five Americans and four Panamanians, with increased Panamanian membership over time. ${ }^{80}$

The Neutrality Treaty, guaranteed perpetual joint defense of the Panama Canal. President Carter believed the U.S. and Panama shared an interest in defending the canal, and this treaty guaranteed a cooperative partnership between the two countries. The treaty stated that the U.S. and Panama have a "responsibility to assure that the Panama Canal will remain open and secure to ships of all nations." President Carter believed the

79 "Panama Canal Treaties Address to the Nation, February 1, 1978," in Public Papers, 1978, Book I, 258.

${ }^{80}$ Panama Hearings, Part 1: 11. 
Panama Canal treaties exemplified his foreign policy vision because they allowed him to correct an unjust and dishonest policy. The treaties demonstrated U.S. respect for Panamanian sovereignty and allowed the U.S. to act as a leader among American countries, fostering cooperation and ultimately promoting peace. ${ }^{81}$

\section{Democratic Ideals}

The two new treaties reflected the Carter administration's respect for democratic values. While the president was aware the treaty would face a great deal of public opposition, he believed the American people would ultimately support his treaty efforts if they were properly informed on the topic. His own personal experience demonstrated that a person's position could change on the issue, especially when they have access to more information. Carter himself had reversed his position on the Panama Canal. During his presidential campaign he vowed to not give up control of the canal. After his election, he asked for a report on the issue and studied the topic further. The report alarmingly concluded that "the most urgent issue the new administration will face in the Western Hemisphere in 1977 is unquestionably the smoldering dispute with Panama.” Once the President became more familiar with the history of the original canal treaty, he realized the need for an updated agreement was vital. Carter believed, the American people would follow his lead and recognize the new Panama Canal treaties were a moral imperative. ${ }^{82}$

Carter argued that Americans "believe in good will and fairness, as well as strength. This agreement with Panama is something we want because we know it is

81 "Panama Canal Treaties Address to the Nation, February 1, 1978," in Public Papers, 1978, Book I, 260. Carter, The White House Diary, 119.; Jimmy Carter: "Treaty Concerning the Permanent Neutrality and Operation of the Panama Canal Joint Statement of Understanding Issued Following a Meeting Between the President and Brigadier General Omar Torrijos Herrera of Panama.,"

${ }^{82}$ Panama Hearings, Part I: 19. 
right." Carter consistently demonstrated a confidence in the American public's ability to judge what was morally right. Carter's concern for justice or fairness is echoed throughout his support of the Panama Canal treaties. He focused in particular on the idea of cooperation of with Panama and the fact that through cooperation both countries could reach agreements that produced mutual benefits. Carter conceded "it is not easy to accept a change which has been so profoundly balanced in our favor and which can now be of equal benefit to both countries. But ours is a great country, and it's great enough to be fair.” Again, Carter recognized the power of acting according to moral standards, and suggested the American people had an exceptional ability to do this. He believed the U.S. could successfully break away from its history of interference and exploitation in Latin American relations. Following the Senate ratification of the Panama Canal treaties he thanked the American people for their commitment to moral principles and their representatives in the Senate "who have done what was right, because it was right." Carter certainly believed in the moral correctness of the Panama Canal treaty policy and felt the American people would rightly favor its ratification if he informed them about the treaties. $^{83}$

The Panama Canal treaties also illustrate the Carter administration's respect for democracy, when considering its efforts to collaborate with Congress. The president believed a greater familiarity with the Panama Canal issue would increase support for the new treaties, although the president admits that the Panama initiative was "the most unpleasant of all," of his efforts to collaborate with Congress. Certainly the issue became

83 "Panama Canal Treaties, Address to the Nation," February 1, 1978, Public Papers, 1978, Book I, 262.; 
quite challenging. The president arranged for forty-four U.S. Senators to visit Panama before the ratification vote took place. Carter was confident the treaties were a bipartisan issue, and U.S. Senator Jacob Javits [R-NY]concurred with his assessment, describing how ratification of the treaties would represent "a great demonstration of the bipartisanship of the foreign policy of the United States." President Carter asked both Republicans and Democrats to unite in support of the Panama Canal treaties because he believed it was in best interest of all people to do so. ${ }^{84}$

President Carter also celebrated the fact that the treaties would face a test of democracy within Panama. The Panamanian Constitution required the people to vote on the treaties in a national plebiscite. He felt that this vote would legitimize the treaties throughout Panama, and also encourage the American people to follow Panamanians in supporting the treaties. While the government of Panama was led by a military dictator, General Omar Torrijos, Carter celebrated the fact that the Panama Canal treaties received democratic approval of the people. The results of the U.N. monitored national plebiscite were by no means unanimous, but over 90 percent of Panamanians reportedly voted and the treaties were approved an approximate two-thirds majority. ${ }^{85}$

The Carter administration also celebrated the international democratic support the Panama Canal treaties had received, particularly from Latin American countries. Secretary Vance told the Senate Foreign Relations Committee that "the democratic

\footnotetext{
${ }^{84}$ Jimmy Carter, interview by Charles O. Jones et al, Carter Presidency Project, November 29, 1982, 22.; Pastor, Exiting the Whirlpool, 8.; U.S. Senate Committee on Foreign Relations, Panama Canal Treaties: Hearings before the Committee on Foreign Relations, United States Senate, $95^{\text {th }}$ Cong., Sess. 1 , Part 1, (Washington, DC: U.S. Government Printing Office, 1977): 4. (hereafter Panama Hearings, with appropriate volume and page numbers).

85 "Voters back treaties 2-1 in Panama," Chicago Tribune, October 24, 1976, 1.
} 
governments of Venezuela, Costa Rica, Colombia, Mexico, and Jamaica issued a joint communique urging the United States and Panama to conclude the new treaties rapidly." ${ }^{\prime 86}$

Equality had also been a contentious issue within the Panama Canal Zone. Racist policies determined the pay and living conditions of those who had worked to build the canal. American employees were paid by a gold standard, while Panamanians and West Indian immigrants were compensated according the silver standard, which was considerably lower. In 1955, an additional treaty agreement was reach between the U.S. and Panama. The Remon-Eisenhower Treaty increased the annual annuity paid to Panama, based on "equitable considerations," included an agreement that the U.S. would construct a bridge across the Canal, and also theoretically prohibited discriminatory pay differentials. The U.S. Congress was slow to fulfill these new treaty obligations. It took more than three years to begin constructing the bridge and Panamanians continued to dominate lower level positions within the Canal Zone, while Americans filled the higher paying specialized positions. As of 1976, the twenty-seven percent of Americans working within the Canal Zone earned nearly fifty percent of Canal Company wages. Despite the American Civil Rights Movement, Panamanians and Zonians-Americans living within the Canal Zone - continued to live within separate spheres in Panama. The 1977 Panama Canal treaties required the Panama Canal Commission give preference to qualified Panamanians when hiring. President Carter sought to correct past discrimination and promote equality. ${ }^{87}$

${ }^{86}$ Panama Hearings, Part 1: 11.

${ }^{87}$ Charles Fenwick, "Treaty Between the United States and Panama," World Affairs 118, no. 3 (Fall, 1955): 70. ;Farnsworth and McKenney, U.S. Panama Relations, 98. 
President Carter believed that the treaties did away with an unequal and exploitative relationship in favor of a more just or equal arrangement. At the treaty signing ceremony on September 7, 1977, the president spoke at length about the Panama Canal treaties representing a fair or just agreement. He sincerely believed the treaties were in the best interest of the United States, Panama, and other countries, who used the canal for trade. The treaties also allowed the U.S. and Panama to maintain security of the Panama Canal. Carter recognized the Canal was more economically significant to Panama than it was to the U.S. Far more valuable than retaining control of the canal, was the prospect of improved relations between the United States and developing countries around the world.

The Carter administration believed the treaties also promoted justice by providing Panama with greater economic benefits. Secretary Vance explained that under the new treaties, Panama received payments "which more fairly reflect the fact that it is making available its major national resource, its territory." The Carter administration did communicate that these fair payments were morally just. Instead, they pragmatically pointed out that the potential for profit would encourage Panama to protect the canal and operate it as efficiently as possible. The Carter administration chose to emphasize pragmatic arguments rather than moral justifications in an effort to promote the treaties as broadly as possible. ${ }^{88}$

President Carter also believed the Panama Canal treaties embodied a "just settlement" between the United States and Panama because they sought to establish a relationship of equality between a large powerful country and a small weaker one. Carter

\footnotetext{
${ }^{88}$ Panama Hearings, Part I: 12.
} 
spoke of "a feeling of a new opportunity for friendship, the recognition of common purpose, cooperation, and mutual respect on an equal basis." The president believed the Panama Canal treaties represented this principle of equality and cooperation. He wished to engage all of Latin America "not as a powerful nation looking down upon a weak nation; not as a father looking down on a son; not as a strong brother looking on a weak brother--but as equals, because I see very clearly we can derive as much or more benefit from good relations with our friends in Latin America even than they can derive from us." Carter truly believed the Panama treaties were truly just or fair because they were mutually beneficial to both the United States and Panama. ${ }^{89}$

\section{Honesty and Transparency}

President Carter also hoped the Panama Canal treaties would reflect his moral principles of honesty and transparency as he led public education campaigns within the U.S. to provide truthful and honest information about the treaties. The idea that education and awareness would convince people to support the treaties reflected the President Carter's moral certitude. The administration estimated that the opposition to the treaties was often "based on misunderstanding and misinformation." Therefore, the administration planned to educate the American public to do the morally correct thing and support the new agreements. Public opinion polls showed informed citizens were more likely to support the treaties. Poll results encouraged the administration to expand its public education campaigns. President Carter hosted fireside chats to answer questions about the treaties, scheduled telephone call-in sessions on the radio, and supported an

${ }^{89}$ Jimmy Carter: "National Hispanic Heritage Week Remarks at a Rose Garden Ceremony.," September 15, 1977, APP. http://www.presidency.ucsb.edu/ws/?pi d=6636 
informational mailing campaign to inform the public about the content of the treaties. In the months leading up to the Senate vote, the President also made a nationwide televised statement in support of the treaties. By involving the public he promoted honesty as well as democratic transparency in the foreign policy process. ${ }^{90}$

President Carter believed pursuing ratification of the Panama Canal treaties was the honest thing to do. The treaties were negotiated over fourteen years during the terms of four previous administrations, and Carter believed following through with a past U.S. commitment was essential. An administration official warned that not following through with the treaties "will invite charges of 'bad faith." One informational mail brochure focused on the four presidents that had committed themselves to negotiating a new treaty with Panama, stressing the idea that Senate ratification would represent the fulfillment of their promise to Panama. President Johnson had made this commitment, in consultations with former presidents Truman and Eisenhower, on December 18, 1964, thirteen years earlier. Not only did President Carter believe the 1903 treaty was immorally deceptive and unjust, he also believed the U.S. had made an honest commitment to Panama and should follow through with the negotiations and ratification of a new treaty agreement. ${ }^{91}$ When negotiating the treaties, Carter also believed it was important to honor the past principles established during the negotiation efforts of his predecessors. The Kissinger-Tack Agreement, was reached during the Ford administration's effort to negotiate a new agreement with Panama. The Carter administration resumed negotiations

\footnotetext{
${ }^{90}$ Carter, "Address to the Nation on the Panama Canal Treaties."; "George Gallup, "Support for Panama Treaties Increases with Knowledge," The Gallup Poll, October 23, 1977, 3.

${ }^{91}$ Memo for Hamilton Jordan, President's Meeting with Panamanian Negotiators, July 28, 1977. Office of the Chief of Staff Files, Hamilton Jordan's Confidential Files, Panama Canal Treaty 6-7/77, Container 36, 59.; Carter, "Address to the Nation on the Panama Canal Treaties."
} 
pledging to adhere to this agreement. The principles included a promise that the revised treaty would have a specific termination date and would allow Panama to claim sovereignty within the Canal Zone. ${ }^{92}$

\section{Respect for Sovereignty}

In 1904, the newly independent country of Panama voted to adopt a new constitution. Knowing that independence depended on the strength of the American naval presence in Panama Harbor, the legislature included a controversial and contradictory guarantee within the Panamanian Constitution. Article 136 of this document stated that "the government of the United State may intervene in any part of the Republic of Panama to reestablish public peace and constitutional order." This clause effectively relinquished Panamanian sovereignty to the United States for the purpose of guaranteeing Panamanian sovereignty, thus subordinating the latter to the former. The U.S., took advantage of this clause, intervening in Panama on several occasions. The U.S. also began to build a strong military presence on the isthmus. ${ }^{93}$

The 1978 Panama Canal treaties attempted to end the seventy-five year power struggle over sovereignty in the Canal Zone. When the treaties were first signed, President Carter refused to acknowledge there was even an issue to debate in regard to sovereignty over the Canal Zone and the Panama Canal. He simply stated "we never had sovereignty over the Panama Canal Zone... We had control of that zone, as though we had sovereignty, but we have recognized the sovereignty of Panama down through the years.” On October 14, 1977 President Carter and General Omar Torrijos of Panama

92 Jorden, Panama Odyssey, 696.

93 David N. Farnsworth and James W. McKenney, U.S.-Panama Relations, 1903-1978: A Study in Linkage Politics. (Boulder: Westview Press, 1983): 22. 
issued a Joint Statement of Understanding to clarify the terms of the new treaties concerned with sovereignty. In this statement, President Carter reaffirmed his belief that the U.S. should not interfere in the domestic affair of other nations. The statement explained that both Panama and the U.S. have a responsibility to insure the Panama Canal "will remain open and secure to ships of all nations." The statement went on to specify that, "this does not mean, nor shall it be interpreted as a right of intervention of the United States in the internal affairs of Panama. Any United States action will be directed at insuring that the Canal will remain open, secure and accessible, and it shall never be directed against the territorial integrity or political independence of Panama.” The Panama Canal treaties reflected the Carter administration's respect for the principle of sovereignty and clearly affirmed a policy of nonintervention in the internal affairs of Panama as a matter of U.S. foreign policy. ${ }^{94}$

\section{Human Rights}

Interestingly enough, despite President Carter's emphasis on human rights, he approached the Panama Canal treaties as entirely separate from human rights policy. Rather than argue the treaties would improve the human rights situation in Panama, the Carter administration emphasized the popularity of the Panama Canal treaties in Panama. President Carter chose to negotiate with General Torrijos despite human rights concerns because the president's priority was taking responsibility for an improper American policy from the past. He subordinated his concern for potential human rights abuses to his

${ }^{94}$ Jimmy Carter, "Panama Canal Treaty Remarks During a Briefing on the Treaty," August 30, 1977, APP, http://www.preisdency.ucsb.edu/ws/?pid=8016. ; Letter to Secretary of State Cyrus Vance from Sol M. Linowitz, May 2, 1977.; Carter, "Treaty Concerning the Permanent Neutrality." 
interest in remedying a serious injustice from the past. He also believed that new Panama Canal treaties would improve the human rights situation in Panama. ${ }^{95}$

President Carter recognized that the Panama Canal treaties were congruous with his human rights policy. Secretary Vance explained that the administration had discussed their human rights concerns with Panama and hoped "closer relations between our two countries that will grow out of the new treaties will provide more positive context in which to express such concerns." The administration also recognized the treaties corrected a past arrangement that exploited the rights of Panamanians by denying them complete political sovereignty. With the abolition of the Panama Canal Zone, they also allowed Panamanians to move more freely within their own country. The Carter administration believed the Panama Canal treaties would maintain the security of the canal, thus preventing violence and potentially protecting the lives of both Panamanians and Americans. ${ }^{96}$

The president realized that problems in Panama were historical and systemic. Carter believed the new Panama treaties would correct these historical grievances focused and encourage institutional reforms that would protect human rights in Panama. The same month Torrijos signed the canal treaties he invited the Inter-American Commission on Human Rights to visit Panama and to report on human rights conditions. The Carter administration also noted that Panama's economic plan specifically aimed to improve human rights. Despite the Panamanian government's dubious record, President

${ }^{95}$ Panama Canal Treaties [United States Senate Debate] 1977-1978: Prepared by the Committee of the Judiciary United States Senate, 95th Cong. (Washington, D.C.: U.S. Government Printing Office, 1978) 96.

${ }^{96}$ Panama Hearings, Part I: 14. 
Carter viewed the treaties a step toward promoting and protecting human rights in Panama. ${ }^{97}$

\section{International Cooperation and U.S. Leadership}

In 1926, the League of Nations was the first international organization to become involved an effort to "arbitrate the question of Panamanian sovereignty." The United States, which never joined the League, opposed such efforts and announced that there was no issues to arbitrate between the U.S. and Panama. Harkening back to the historical precedent established with the Monroe Doctrine, the U.S. stated it would not allow for any external influence whatsoever to interfere with its relations with the Republic of Panama. Despite past hostility towards international arbitration of a new canal treaty, President Carter hoped to use international organizations to promote cooperation and maintain peace throughout the world. ${ }^{98}$

The Panamanian government had successfully internationalized the treaty issue in the early 1970s. Not only did Latin American leaders, support Panama's demand for revisions to the 1903 treaty, countries throughout the world supported this small nation as well. In 1973, Panama, as a member of the U.N. Security Council, successfully lobbied for a Security Council meeting to take place in Panama. The United States, led at the time by President Richard Nixon, opposed such a meeting, citing concerns about increasing tensions in the region, and knowing that Panama would likely gain international sympathy for their treaty demands at such a meeting. The U.S. failed to convince other Security Council members to oppose a meeting outside of the United States. In the end,

\footnotetext{
${ }^{97}$ Panama Hearings, Part I: 14.

${ }^{98}$ David Farnsworth and James W. McKenny, U.S.-Panama Relations, 1903-1978: A Study in Linkage Politics, (Boulder: Westview Press, 1983): 25-26.
} 
the meeting was held, but at Panama's expense, demonstrating just how committed Panama was to drawing international attention to the treaty issues and increasing pressure on the U.S. to negotiate new treaties. In an effort to limit international criticism, the U.S. took a huge step towards integrating the Panama Canal Zone into Panamanian territory. Before the meeting took place, the U.S took down the fences that separated the Canal Zone from Panama. ${ }^{99}$

The Security Council meeting was regarded as a great success throughout Panama. Not only had it encouraged the U.S. to take down the physical barrier that divided the country, but Panama had also introduced a motion demanding revisions to the 1903 treaty. The motion was supported by all Security Council members, except Great Britain, which abstained from the vote, and the United States. The United States used its veto for the third time in history to defeat the resolution. Despite its failure, Panamanian Foreign Minister Juan Antonio Tack viewed these results favorably. He concluded that "The United States has vetoed Panama's resolution, but the world has vetoed the United States." It appeared that the cause of Panama was becoming the cause of all mankind. ${ }^{100}$

The Carter administration recognized the Panama Canal treaties were "the single most positive action to be undertaken in recent years in our relations with Latin America." President Carter spoke of the treaties as symbolic of a new foreign policy direction in the region. On February 1, 1978, the President made a televised address to the American public about the importance of the Panama Canal treaties. Carter turned

99 "Telegram From the Mission of the United Nations to the Department of State," FRUS, 19691976, V: 242. "Telegram from the Department of State to the Mission to the United Nations," FRUS, 19691976, V: 243.

${ }^{100}$ Tom Long, Latin America Confronts the United States: Asymmetry and Influence, (New York: Cambridge University Press, 2015): 90. 
once again to the past for inspiration. Carter quoted the same celebratory rhetoric Teddy Roosevelt had used when the Panama Canal was first opened, describing the treaty efforts as "the lift toward nobler things which marks a great and generous people." The Carter administration was proud of the treaties, because they represented a foreign policy based on the moral principles of justice, fairness, and cooperation. They also demonstrated the administration's preference for diplomatic negotiation as opposed to military coercion or covert action. Carter described how he felt a "new sense of equality, a new sense of trust and mutual respect that exists because of the Panama Canal treaties," among Latin American nations. ${ }^{101}$

The signing ceremony for the treaties was a lavish and celebratory affair. Representative from 27 American countries attended, including 19 heads of state. Those aware of the human right records of some of the Latin American dictators who were present at the signing did not celebrate this occasion as a positive example of international cooperation and American solidarity. While a few treaty opponents protested outside of the Pan American building on the night of the signing, an even larger group of protesters gathered to protest human rights abuses in the Chile and Uruguay. One critic likened the dictators of Paraguay, Uruguay, and Bolivia who were present at the signing ceremony to "Franco, Hitler, and Stalin," and described them as "the most motley collection of butchers ever assembled.” President Carter however met with each of the Latin American leaders, hoping to express the United States' commitment to human rights and international cooperation. ${ }^{102}$

101 Panama Hearings, Part I, 11.

102 "A List of the Leaders at Treaty Ceremony," New York Times, 8 Sept. 1977, 11.; Quoted in Renouard, Human Rights in American Foreign Policy, 142. 
The Carter administration recognized the canal treaties were not simply a bilateral issue between the U.S. and Panama; Carter stressed that they were also of international importance since countries around the world utilized the Canal for shipping. The administration commented with pride that the canal "has been run as a public service for the nations of the world rather than a business," for sixty-two years. The canal's designated toll were set to sustain the canal's operation rather make a profit. In fact, the toll rate only increased nine cents over the six decades before the 1977 treaty debate began. The Canal treaties were therefore important to the Carter administration, because they sought to internationalize its foreign policy and work to benefit the world as a whole. $^{103}$

Carter described how the "treaties will increase our Nation's influence in this hemisphere, will help to reduce any mistrust and disagreement, and they will remove a major source of anti-American feeling." Carter believed the old Panama treaty damaged the United States' ability to act as a moral leader in Latin America and throughout the world. Again, the administration's vision of U.S. moral leadership and the principle of honesty were reflected in the Panama Canal treaties. The treaties also certainly benefited the people of Panama by returning the canal to the people with sovereign rights to the land, and also maintaining peace. The treaties did away with the Panama Canal Zone, making the nation whole for the first time in its history. President Carter also stressed the importance of the canal remaining neutral so that all countries could benefit from trade through the waterway. ${ }^{104}$

${ }^{103}$ Farnsworth and McKenney, U.S. Panama Relations, 21.

${ }^{104}$ Memo for Hamilton Jordan, President's Meeting with Panamanian Negotiators, July 28, 1977. Office of the Chief of Staff Files, Hamilton Jordan's Confidential Files, Panama Canal Treaty 6-7/77, 
The U.S. sought to reestablish itself as an exemplary leader in the world rather than a colonial power. One treaty negotiator, Sol Linowitz, testified before the Senate Foreign Relations committee that "all countries of the hemisphere have made common cause in looking upon our position in the canal as the last vestige of a colonial past which evokes bitter memories and deep animosities." Instead of overtly exploiting other countries, the Carter administration hoped to engage other countries through diplomatic efforts and promote American moral values throughout the world. William J. Jordan argues that the Panama Canal treaties demonstrated, "the way in which a great world power tried and succeeded in working out new arrangements for dealing with a small, nearby nation in an effort to maximize the benefits for both." The treaties were an opportunity to revitalize American foreign policy by resolving problems from the past. ${ }^{105}$ Secretary of State Cyrus Vance echoed Sol Linowitz's sentiments. The treaties "prove, once and for all, the falsity of the tired charges that we are imperialistic exploiters bent only on extracting Latin American raw materials and using the continent for our own economic interests." The Carter administration saw the treaties as redemptive, an embodiment of the Carter administration's moral policies. The president triumphantly declared that "the entire hemispheric interrelationship had been changed by my pursuit of human rights and by the symbolism of the Panama treaty.” The treaties represented a new direction in American foreign policy. ${ }^{106}$

Container 36, 59.; Carter, "Address to the Nation on the Panama Canal Treaties."; Jimmy Carter: "National Hispanic Heritage Week Remarks at a Rose Garden Ceremony.," September 15, 1977, APP. http://www.presidency.ucsb.edu/ws/?pi d=6636

${ }^{105}$ Carter, "Address to the Nation on the Panama Canal Treaties."; Panama Hearings, Part I: 201.; Jorden, Panama Odyssey, xv.

${ }^{106}$ Panama Hearings, Part 1: 11. 
Carter also believed the Panama treaties would convey U.S. values to other counties of the world. With the treaties, Carter planned to "demonstrate that as a large and powerful country, we are able to deal fairly and honorably with a proud but smaller sovereign nation." Again stressing his respect for sovereignty, Carter hoped to deemphasize power relations and focus instead on developing mutually beneficial diplomatic relationships. He declared ratification of the treaties would "mark the beginning of a new era in our relations not only with Panama but with all the rest of the world. They symbolize our determination to deal with the developing nations of the world, the small nations of the world, on the basis of mutual respect and partnership." The Panama Canal treaties allowed President Carter to successfully demonstrate to the world his belief that powerful counties should not exploit weaker nations; instead he felt they should assume leadership roles and promote human progress. ${ }^{107}$

\section{Promoting Peace}

Carter also believed the Panama Canal treaties were essential to maintaining peace and stability. President Carter's Chief of Staff Hamilton Jordan speculated that if the treaties failed it would "increase the likelihood of major incidents in Panama." President Carter made it clear that if the treaties were not ratified he knew it would be his "responsibility to defend the canal against any such threat." Publically, he worried if the treaties were not ratified "there might be some attempt to disrupt the canal." He was conscientious of the Joint Chiefs of Staff estimate that it would take approximately 100,000 U.S. troops to defend the canal and cautioned "if the canal treaties should be

${ }^{107}$ Carter, "Address to the Nation on the Panama Canal Treaties."; Jimmy Carter: "Panama Canal Treaties Remarks at the Signing Ceremony at the Pan American Union Building," September 7, 1977, Papers of the President, 1977, Book II, 1543. 
rejected by the Senate, it would be a severe blow... and under those circumstances I

would probably have to take emergency action." President Carter's commitment to peace encouraged him to ardently promote the treaties to prevent potential violence. ${ }^{108}$

The potential for violence in Panama was quite real after a violent confrontation took place between Panamanians and Americans in 1964, which resulted in the death of twenty five people — four U.S. Army officers and 21 Panamanians. ${ }^{109}$ Because of this real threat of violence, the Carter administration viewed the successful negotiation of the treaties as "a triumph for the principle of the peaceful and constructive settlement of disputes between nations." Rather than the use military force to achieve foreign policy objectives, diplomacy curbed potential violence and maintained peace, which Carter valued so highly. ${ }^{110}$

The administration also emphasized that representatives of the Joint Chiefs of Staff had worked with treaty negotiators to ensure the treaties were in the best interest of the U.S. militarily. Privately Carter wrote in his diary on the day of the Senate vote that he was "anticipating massive violence in Panama if the treaties were defeated." The

${ }^{108}$ Memo for Hamilton Jordan, President's Meeting with Panamanian Negotiators, July 28, 1977. Office of the Chief of Staff Files, Hamilton Jordan's Confidential Files, Panama Canal Treaty 6-7/77, Container 36, 59.; Jimmy Carter, "Panama Canal Treaties Question-and-Answer Session by Telephone with Participants in a Townhall Meeting on the Treaties in Albuquerque, New Mexico," January 17, 1978, APP, http://www.presidency.ucsb.edu/us/?pid=30778.; Panama Hearings, Part I, 12.; Carter, Keeping Faith, 177.

${ }^{109}$ The 1964 riots were sparked by a conflict over symbolic sovereignty within the Canal Zone. The question of whether the flag of the U.S. or the Panamanian flag should fly within the Panama Canal Zone was widely debated. Violence erupted when a group of Panamanian students attempted to fly the Panamanian flag outside a school within the Canal Zone. In the conflict that followed, the Panamanian flag was ripped, and rioting followed.

${ }^{110}$ I. Roberto Eisenmann Jr. "Panama and the United States," Revista Harvard Review of Latin America XII, no. 3 (Spring 2013): 10. Panama Hearings, Part 1: 7, 9.; Jimmy Carter: "Panama Canal Treaties Remarks at the Signing Ceremony at the Pan American Union Building," September 7, 1977, Papers of the President, 1977, 1, 1543. 
threat to the canal was quite real to the president and he certainly dreaded the prospect of having to take military action in Panama. ${ }^{111}$

While the Carter administration largely ignored accusations that the Torrijos regime was committing human rights abuses, the maintenance of peace was essential to preserving the human right to life. President Carter predicted an inevitable military engagement in Panama if the treaties were not ratified in the Senate. Such action would certainly cost both American and Panamanian lives. Acting to prevent such a conflict can therefore be construed as acting to protect human rights. In addition to preserving the peace, turning the Panama Canal over to Panamanians promoted their economic rights. Like his presidential predecessors, security concerns motivated the President Carter to support the Panama Canal treaties. These concerns cannot be separated from moral motivations because they so closely relate to preserving the peace. Upon signing the treaties Carter stated they "mark the commitment of the United States to the belief that fairness, and not force, should live at the heart of our dealings with the nations of the world." The dual goals of peace the justice are again embodied within the Panama Canal treaty initiative. ${ }^{112}$

${ }^{111}$ Memo for Hamilton Jordan, President's Meeting with Panamanian Negotiators, July 28, 1977. Office of the Chief of Staff Files, Hamilton Jordan's Confidential Files, Panama Canal Treaty 6-7/77, Container 36, 59.; Jimmy Carter, "Panama Canal Treaties Question-and-Answer Session by Telephone with Participants in a Townhall Meeting on the Treaties in Albuquerque, New Mexico," January 17, 1978, APP, http://www.presidency.ucsb.edu/us/?pid=30778.; Panama Hearings, Part I, 12.; Carter, Keeping Faith, 177.

${ }^{112}$ I. Roberto Eisenmann Jr. "Panama and the United States," Revista Harvard Review of Latin America XII, no. 3 (Spring 2013): 10. Panama Hearings, Part 1: 7, 9.; Jimmy Carter: "Panama Canal Treaties Remarks at the Signing Ceremony at the Pan American Union Building," September 7, 1977, Papers of the President, 1977, 1, 1543. 


\section{CHAPTER IV:}

\section{OBSCURING A VISION: THE TREATY DEBATE}

The conservative opposition to the Panama Canal treaties reflected a worldview in sharp opposition to the Carter Administration's foreign policy vision. The opposition framed the treaties as yet another American retreat. A newspaper editorial published in the Richmond News Leader bemoaned that "already America has met stalemate in Korea and debilitating defeat in Southeast Asia. Slowly, American has begun to retreat...Will the fall of the Panamanian domino signal yet another backward step?" Such allusion to the Domino Theory, demonstrated that the American public feared communism in Panama. The rhetoric of treaty opponents also often reflected such Cold War concerns. ${ }^{113}$

Opponents of the Panama Canal treaties successfully obscured the Carter administration's foreign policy vision, encouraging the administration to increasingly favor pragmatic arguments rather than moral justifications for the Panama Canal treaties. Passionate arguments opposing the Canal treaties challenged the president's credibility, dedication to moral ideals, and reputation as a strong and confident leader. Opponents successfully took advantage of the inherent contradictions within the Carter administration's human rights policy, and presented counter arguments that conflicted with each aspect of President Carter's foreign policy vision. Like Carter, treaty opponents used historical arguments to support their position. The strength of the opposition and

${ }^{113}$ Quoted in Thomas A. Houllihan, "The Public Controversy," 373. 
administrative miscalculations resulted in the Carter administration failing to coherently communicate how the new treaties reflected the administration's foreign policy vision. Arguments the administration put forth to support of the treaties were muddled as treaty opponents directly contradicted them with their own arguments.

The Panama Canal issue had a decade-long history of opposition within the Senate when the Carter administration set out to negotiate new treaties. During the 1977 ratification debate, congressional opponent made passionate arguments for the U.S. to keep indefinite control of the Panama Canal. A variety of conservative political organizations fought against the treaties, leading vigorous public campaigns aimed at halting their ratification. Some of these organizations were created to fight treaty ratification specifically, while others had operated for years and gained political momentum by adopting the treaty issue. The GOP also issued a statement opposing the treaties, as did conservative leader and former Governor of California Ronald Reagan. Scholars, including Adam Clymer and David Skidmore, have noted that the Panama Canal issue strengthened these "New Right" political groups. Despite the fact that they did not successfully stop the ratification of the treaties, they mobilized American conservatives against the treaties and the Carter administration that negotiated them.

\section{Historical Inspiration}

Historian George Moffett blamed ill timing and the power of public nostalgia for the fierce debate over the Panama treaties. Such an assessment suggests the Carter administration had little control over the results of the treaty debate, which seems to be far from the truth. President Carter and his administration were very involved in the 
debate and campaign for Senate ratification of the treaties. They even adjusted the rhetoric they used to promote the treaties in an attempt to avoid opposition attacks. ${ }^{114}$

Senators on the Foreign Relations Committee debated whether the history of the canal should be considered when deciding whether or not to ratify the new canal agreement. Senator Richard Clark [D-IA] remarked “I don't think any nation can deny its past history or should want to." He recognized that the new Panama treaties had historical inspiration and believed it was necessary to study the root of the canal dispute between the U.S. and Panama before deciding whether to ratify the treaties. History had certainly been President Carter's first consideration when he considered negotiating new treaties. Senator Baker refused to let feelings of guilt influence his decision making and denied the significance of the past. He was adamant that he would not feel "ashamed of the Panama Canal," and emphasized the "need to decide what is best for the country in the future, not what we did in the past." Senator Hubert Humphrey argued that ratification of the Panama treaties would "add substance and character to the good neighbor policy first enunciated by President Roosevelt." Humphrey saw the treaties as a continuation of past Latin American policy. ${ }^{115}$

American treaty opponents summarized the history of the Panama Canal very succinctly as they shouted "We built it! We paid for it! We own it!" In regard to the first claim, certainly the U.S. had led the efforts to build the Panama Canal. Both President Carter and treaty opponents celebrated the construction of the canal. Unlike the president, opponents argued that since the U.S. was responsible for its construction, the country had

\footnotetext{
${ }^{114}$ Moffett, The Limits of Victory, 112.

${ }^{115}$ Panama Hearings, Part 1: 7, 9.
} 
earned the right to indefinitely control it, just as the original 1903 treaty stipulated. Many Americans saw the canal as symbol of American strength and accomplishment. ${ }^{116}$

Opponents also insisted "we paid for it!" stressing that not only did the U.S. pay an initial amount to Panama for construction rights and control of the Canal Zone, the U.S. also paid an annual annuity which had been incrementally increased over the years. Opponents also claimed that the U.S. had essential paid for the canal twice. The second payment, in the amount of $\$ 25$ million was made to Colombia for violating the first agreement to construct a canal through the Colombian province of Panama.

Treaty supporters and opponents both speculated about the future of the Panama Canal. During a January 1978 debate with William Buckley on Firing Line, Ronald Reagan drew a parallel between Egypt's nationalization of the Suez Canal and Panama's potential to nationalize the canal. In response to this concern, Secretary Vance simply argued that the treaties reduced the risk of Panama nationalizing the Canal. He dramatically speculated during a Foreign Relations Committee hearing in the Senate that if the treaties were to fail, "our relations with Panama would be shattered, our standing in Latin America damaged immeasurably, and the security of the canal itself placed in jeopardy." Opponents and supporters of the treaties made historical assumptions and future predictions in an effort to support their arguments. ${ }^{117}$

The Carter administration started to increasingly favor pragmatic arguments as the Senate vote to ratify the treaties approached. The administration likely recognized that moral arguments could inspire a disquieting sense of shame, at a time when the public

\footnotetext{
${ }^{116}$ Clymer, Drawing the Line at the Big Ditch, 30.

${ }^{117}$ Panama Hearings, Part I: 19.
} 
was already wary of dubious foreign policy and the declining strength of the U.S. in the world following the Vietnam War. Testifying before the Senate Foreign Relations Committee, Cyrus Vance stated that the primary reason to ratify the treaties was because "these treaties protect and advance the national interests of both the United States and Panama." While concern for the national interests of a developing nation reflected an international broad foreign policy, Vance did not specifically mention the historical inspiration for new treaties. He simply stated the new treaties should be ratified "because of the responsible way they resolve complex and emotional issues which have been with us for most of this century." This vague allusion to the historical inspiration for the canal treaties exemplifies the Carter administrations shift in tactics. When the treaties were signed in September of 1977, President Carter emphasized moral arguments much more than his administration did in the months leading up to the Senate vote in spring of 1978.

\section{Democratic Ideals}

Treaty opponents challenged President Carter's democratic values, criticizing the fact that Carter negotiated with a Panamanian dictator. General Torrijos seized power in Panama in 1967 in a military coup. Despite his authoritarian leadership style, President Carter offered a positive assessment of Torrijos' character. He wrote in his diary that he was largely impressed with the Panamanian leader. President Carter's willingness to negotiate with a dictator encouraged opponents to challenge his commitment to democracy. Conservative opponents often suggested Torrijos and Carter were coconspirators in a Cold War narrative. ${ }^{118}$

${ }^{118}$ Carter, White House Diary, 87. 
The Carter administration was unable to acknowledge concern over Torrijos' governing style because such criticism would certainly have created backlash in Panama. Since the president could not justify his decision to negotiate and meet with undemocratic leaders, the administration simply ignored this criticism, thus inspiring even more speculation about his values and doubts about the coherency of his human rights policies. In reality, Carter had many moral reasons to pursue negotiations, even if he had to do so with a repressive regime. During his presidential campaign he had discussed this very topic in a NBC news interview. When asked about the "morality of liaisons with dictatorships," Carter once reflected upon his religious convictions to explain his perspective. "God says, 'judge not, that ye be not judged' [Matthew 7:1]. Just because I believe in democracy it doesn't mean I think that people who live in countries that might have a different form of government....are wrong." Carter also cited the golden rule and explained that "what's best for those people who live in the country with which we are dealing?" should be a primary consideration. President Carter proved he was willing to negotiate with a dictator to purse a new canal agreement that aligned with his moral principles, but he could not justify this position to the American public. ${ }^{119}$

President Carter also believed that the Panama Canal treaties would promote democracy in Panama. Carter observed that many improvements were made even before the treaties were ratified. People were granted more political freedom, and were able to participate in a national plebiscite to demonstrate whether they supported the new canal treaties. According to Freedom House, many of the restrictions on the Panamanian media were lifted once the treaties were signed. The two United Nations human rights covenants

${ }^{119}$ Pippert, The Spiritual Journey, 101. 
that President Carter had signed were also ratified in Panama in 1977. The U.S. Senate did not ratify them until 1992. While President Carter likely disapproved of the authoritarian nature of the Torrijos regime, Carter felt it was more important for a democratic country to act according to its own values, than refuse to negotiate with a particular type of government. Carter believed signing the treaties had expanded freedom in Panama, and he felt ratification of the treaties would continue this trend. ${ }^{120}$

Opponents criticized the Carter administration for its appointment of Sol Linowitz to the treaty negotiating team. President Carter, in an effort to promote expediency, appointed him as a special negotiator. Since his term of service was limited to six months, his appointment did not require congressional approval. Opponents accused the president of attempting to dodge Congress rather than cooperate with the legislative branch. They insinuated that President Carter's actions revealed he was hiding something about Linowitz's appointment and suggested that Linowitz was motivated by his own business interests in Panama. In an attempt to quell such accusations, Linowtiz stepped down from his position as. This decision only fueled opposition claims that Linowtiz had conflicting interests and should not have negotiated the new canal treaties with Panama. $^{121}$

Treaty opponents were critical of the Carter administration's decision to pursue Senate ratification of the Canal treaties because they argued that the public overwhelmingly opposed the treaties. Secretary of State Vance described how the administration felt it was "on the threshold of an important period in American

${ }^{120}$ Panama Hearings, Part II: 102.

${ }^{121}$ Clymer, Drawing the Line at the Big Ditch, 47. 
diplomacy," because the president had the "confidence and support of the American people." Such support, especially when considering the Panama Canal treaties, seems to have been illusionary. David Skidmore discusses the widespread unreliability of public opinion polls on the treaties, and concluded a majority of Americans opposed the treaties. Bernard Rochco's study of the same topic indicated that public opinion poll results varied dramatically depending on the wording of questions. He estimated for every five Americans who opposed the treaties, only three supported them. The Carter administration believed they "were quite successful," changing public opinion. Carter's argument that public support had shifted in favor of the treaties may have even convinced some undecided senators to vote for ratification of the treaties. ${ }^{122}$

Treaty opponents also challenged the Carter administration's claim that the treaties were just. They voiced concerns Zonians in particular, whose lives would undoubtedly change once there was no longer a Canal Zone in Panama. The Zonians however were guaranteed their jobs through retirement, hence the importance of the interim period before turning the canal over to Panama. Opponents also voiced concern about whether Panamanians were capable of successfully running the canal operations. The Carter administration sought to quell such jingoistic, if not blatantly racist sentiments. Ellsworth Bunker guaranteed it was "possible to build up a fully qualified Panamanian workforce," before transferring the canal to Panamanian control at the end of the century. Bunker was careful not to insult the Panamanian people, noting that in 1977

${ }^{122}$ Vance, Hard Choices, 44.; David Skidmore, Reversing Course: Carter's Foreign Policy, Domestic Politics, and the Failure of Reform, (Nashville, TN: University of Vanderbilt Press, 1996): 124.; Bernard Roshco, “The Polls: Polling on Panama-Si; Don’t Know; Hell, No!” The Public Opinion Quarterly 42, no. 4 (Winter, 1978): 562.; Jimmy Carter, interview by Charles O. Jones et al, Carter Presidency Project, November 29, 1982, 22. 
seventy-four percent of canal employees were Panamanian. He recognized that "we of course start from a strong base," of Panamanian workers ready to operate the canal. ${ }^{123}$

\section{Honesty and Transparency}

There was a lot of finger-pointing on both sides of the treaty issue, when it came to the truthfulness of debate arguments. One of the most prominent public supporters of the treaties outside of politics was John Wayne. He wrote a letter to Ronald Reagan, offering to show him "point-by-God-damn-point in the Treaty where you are misinforming people." This amount of outrage was common on both sides of the treaty debate and likely created confusion among American public, who certainly had less access to information about the treaties than the politicians involved in the debate in Washington. ${ }^{124}$

Senate opponents also blatantly challenged the president's commitment to honesty. In October of 1977, less than a month after Carter signed the canal treaties, Senator Robert Dole [R., Kan.] publically leaked a classified document related to treaty negotiations. The leaked cable from Panama raised questions about the United States' right to permanently defend the canal. Panama wanted reassurances that this permanent defense agreement would not infringe on the political independence and sovereignty of the country, pointing out "intervention is simply forbidden by international law." Senator Dole, despite being faced with an ethics violation for the leak, suggested Panama's position was threatening. He compared his revelation to a recent historical example of government deceit. "We should have learned from Watergate that we can never again

${ }^{123}$ Panama Hearings, Part I: 17.

${ }^{124}$ Quoted in Pastor, Exiting the Whirlpool, 7. 
allow a 'national security' classification to be used in such a way as to mislead the American people," Dole bemoaned. The leaked Panama cable allowed opponents to publically question the Carter administration's commitment to honesty and was impetus for the aforementioned Joint Statement of Clarification, signed by both Carter and Torrijos. The agreement reaffirmed the U.S. commitment to not interfere in the internal affairs of Panama in an effort to defend the canal. The leak may also have damaged the president's credibility and his ability to effectively make moral arguments to support ratification of the Panama treaties. ${ }^{125}$

Treaty opponents also argued about the strategic and economic importance of the Panama Canal. President Carter pointed out that many military vessels and even some tankers were too large to pass through the canal, thus the canals importance was in decline. The president considered constructing a sea-level canal was a potential option in the future, and emphasized that the treaties included provisions that protected U.S. interests in such a construction project in Panama. Alternatively, treaty opponents emphasized that controlling the Panama Canal was absolutely vital to U.S. interests.

Members of the U.S. Senate noted the contradictions in political commentary about the treaties. Senator John Glenn [D-OH] remarked "I think in the mail and the media, there have been more conflicting statements about Panama, and more conflicting views expressed as to what this treaty does than anything I have seen recently." The public was likely confused by such contradictory arguments. Senator Richard Stone [DFL] was critical of the "battle of the propaganda on both sides," of the treaty debate.

125 "Leaked note endangers Panama Canal treaties," Chicago Tribune, October 6, 1977, 1. 
Conflicting information called into question the honesty of those on both sides of the debate. ${ }^{126}$

Opponents to the Panama Canal treaties raised many doubts about the Carter administration's honesty. This was a serious problem for a president who had pledged time and time again to never lie to the American people. The Carter administration often dismissed opposition arguments, ignoring them altogether or claiming they were misinformed. They also accused treaty opponents of being deceitful. Such contradictory arguments left the public confused about the real goals and terms of the Panama Canal treaties. It was quite difficult for the public to know who to believe.

\section{The Question of Sovereignty}

When American treaty opponents protested the Canal Treaties, they also proclaimed "We own it!" The debate over sovereignty appeared to be an irreconcilable conflict. Both sides of the debate refused to acknowledge the premise of their opponent's arguments. Those who objected to the new Panama treaties, including Ronald Reagan, argued the Canal Zone was "sovereign American territory, every bit the same as Alaska and all the states that were carved out of the Louisiana Purchase." In contrast, supporters of the treaties summarily dismissed claims that the Canal Zone had the same territorial status as an American state. Such a response may have even encouraged discontent with the Carter administration's Panama Canal policy, as nobody welcomes being labeled uninformed. By simply claiming the U.S. never had sovereign rights within the Canal

${ }^{126}$ Panama Hearings, Part 1: 6. 
Zone, President Carter lost an opportunity to clarify its position that the U.S. should and would be respecting sovereignty of other countries, including developing countries. ${ }^{127}$

The Chairman of the American Conservative Union, Representative Philip Crane [R-IL], authored a book opposing the treaties, entitled Surrender in Panama. This book, along with millions of mass mailings sent out by Crane's organization and other conservative anti-treaty groups increased public opposition to the treaties. These groups successfully organized grassroots campaigns against the treaties, encouraging Americans to write to their Senators to voice their concerns. The American Conservative Union also aired a television program which argued emphatically about sovereignty, claiming that "There is no Panama Canal. There is an American Canal at Panama." Opposition claims continued to conflict dramatically with the arguments the Carter administration championed. $^{128}$

Treaty opponents may have been misinformed about the legal distinctions between the Zone and U.S. territory, but they certainly did recognize that the U.S. had acted as if it were sovereign in the Panama Canal Zone for a majority of the twentieth century. While the Carter administration recognized a neocolonial relationship between the U.S. and Panama existed, they chose not to argue this point. Perhaps the Carter administration thought the U.S. Congress and the American public were not willing to confront this history of exploitation. President Carter may have been ill advised in dismissing popular and poignant arguments against the treaties. The original treaty did

${ }^{127}$ Ronald Reagan quoted in Thomas A. Houllihan, "The Public Controversy Over the Panama Canal Treaties: An Analysis of American Foreign Policy Rhetoric," Western Journal of Speech Communication 50 (Fall 1986): 373.

${ }^{128}$ Adam Clymer, "TV Campaign Begun Against Panama Canal Treaty," New York Times, October 31, 1977, 20. 
indeed state that the U.S. retained "all rights, power and authority within the zone mentioned...which the United States would possess and exercise if it were the sovereign of the territory...to the entire exclusion of the exercise by the Republic of Panama of any sovereign rights, power or authority." Carter's argument that the U.S. did not have sovereignty over the Canal Zone seemed to be incongruent with decades of political reality. ${ }^{129}$

It was not only President Carter and his administration who thought arguments of treaty opponents reflected ignorance. Senators were also critical about the apparent lack of public knowledge about the treaties. Senator Claiborne Pell [D-RI] hoped the Senate Foreign Relations Committee hearings would "gradually turn around this public opinion." In reference to the mass amounts of mail he and other senators received in opposition to the treaties, he doubted "if anybody who sent us a post card has read the full text of the treaty." Such doubts suggest that treaty supporters, including Senator Pell and President Carter, simply believed that with the proper information everyone would logically support the treaties. Assumptions such as these encouraged treaty supporters to dismiss opposition arguments as the ramblings of uninformed reactionaries. ${ }^{130}$

The question of sovereignty became a heated issue when the Senate debated the DeConcini Reservation. This amendment implied the U.S. had the authority to use force within Panama if there were internal threats to the canal. The amendment raise questions about the United States' respect for Panamanian sovereignty, and caused a great deal of outrage in Panama. The Carter administration had to take action to ease tensions. First,

\footnotetext{
${ }^{129}$ Crane, Surrender in Panama, 7.
}

${ }^{130}$ Panama Hearings, Part 1: 5. 
President Carter recognized the amendment was "a violation of my agreement with Torrijos,"and urged the Senate to reject it. When it was approved as part of the Neutrality Treaty, Carter concluded "the Panamanians need a restatement of the principle of nonintervention." He worked with Senate leaders who agreed the Panama Canal Treaty would include an amendment affirming U.S. respect for Panamanian sovereignty using the same wording of the Joint Statement of Understanding Carter had made with Torrijos had used. Carter clarified that the U.S. did "not have the right to interfere in Panama's internal affairs. That is a right we neither possess nor desire." President Carter made the position of restraint and respect for sovereignty public and clear with the Panama Canal treaties. $^{131}$

\section{The Human Rights Contradiction}

Ironically, conservative opponents claimed the human rights cause as their own in an effort to gain supporters and successfully block treaty ratification. In an effort to mobilize more citizens against the new canal agreement, conservatives emphasized human rights concerns in Panama. Many Americans who supported the Carter administrations human rights efforts were already alarmed that Carter had met with Augusto Pinochet in September 1977, when the Chilean dictator attended the Panama Canal treaty signing ceremony. This meeting had resulted in international observers gaining access to Chile, but it appeared quite hypocritical to critics of Chile's repressive military dictatorship. One protestor complained that the Carter "administration is all lip,

${ }^{131}$ Carter, Keeping Faith, 172-3.; Memo to National Security Advisor Zbigniew Brzezinski from Robert Pastor, April 10, 1978.; Carter, "Panama Canal Treaty Remarks During a Briefing on the Treaty."; While the Carter administration adhered to this commitment, the 1989 U.S. invasion of Panama, Operation Just Cause, that removed Noriega from power demonstrates that the tentative nature of foreign policy pledges. 
all words." Liberals were certainly critical of Carter's human rights record. Because the administration favored increasingly pragmatic arguments to promote the treaties, the public had little reason to view the Panama Canal treaties as consistent with Carter's moral foreign policy. The Carter administration appeared to have abandoned the idealistic foreign policy vision President Carter had described during his inaugural address. ${ }^{132}$

Treaty opponents championed "human rights" concerns in Panama, adopting one of the most fundamental aspects of the Carter administration's foreign policy as their own. They publicized testimony heard before the Senate of a Panamanian widow whose husband, Leopoldo Aragon, was illegally detained by the Panamanian government. Upon his release, he fled to Sweden where he protested the Panama Canal treaties in front of the U.S. embassy by self-immolation. Opponents drew attention to this extreme form of protest and the human rights abuses that inspired it. In doing so they also challenged the Carter administration's commitment to its stated moral principles. ${ }^{133}$

Anti-treaty activists accused the Torrijos government of committing human rights abuses. They voiced concern that Carter's decision to negotiate with a dictator gave his government legitimacy. Treaty opponents also worried about the stability of the Torrijos regime and whether the treaties would be successfully enforced in Panama. Such hypothetical concerns were difficult to address. There was also a lack of credible information about the extent of human rights violations in Panama. It was clear that Torrijos' regime was responsible for limiting freedom in Panama. When Torrijos seized power in Panama, a new constitution was drafted to give him ultimate authority within

\footnotetext{
${ }^{132}$ Quoted in Renouard, Human Rights in American Foreign Policy, 142.

${ }^{133}$ Panama Hearings, Part II: 257.
} 
government. When the Carter administration attempted to sell the Panama Canal treaties to the American public, they avoided the topic of human rights altogether. In fact President Carter's assessment of Torrijos was largely positive. Carter described him as charismatic leader. Such praise and respect, conflicted with treaty opponent's claims that Torrijos was "a little tinhorn dictator."134

President Carter claimed the U.S. "cannot look away when a government tortures people, or jails them for their beliefs." Yet the Torrijos government was responsible for such human rights violations and the Carter administration did not acknowledge them. Opponents to the treaties made the public question Carter's commitment to human rights, and perhaps even more damaging, his pledge to be honest with the American public and include them in the democratic process. The Carter administration had braced for such attacks in regard to their human rights policy. The Presidential Review Memorandum issued in early July 1977 studied human rights policies and concluded "potentially unavoidable inconsistencies, particularly in the public eye, will expose us to severe criticism." Knowing this, President Carter continued to pursue the Panama Canal treaties because he ultimately believed they were consistent with his goals and values. ${ }^{135}$

It is unclear what knowledge the Carter administration had regarding human rights abuses in Panama. The OAS carried out an investigation to determine the prevalence of abuse, but its report was not complete until after the canal treaties were ratified. The report concluded that the Panamanian government was responsible for thirty-four extrajudicial deaths during the years Torrijos was in power. The OAS reported

${ }^{134}$ Clymer, Drawing the Line at the Big Ditch, 30.

${ }^{135}$ Pastor, Exiting the Whirlpool, 41.; "Presidential Review Memorandum on Human Rights," July 8, 1977, State Department, 14. 
the government had also illegally detained and the tortured prisoners. The report did indicate that the frequency of such abuses declined from when Torrijos first came to power in 1968 to 1977 , when the Panama treaties were signed. ${ }^{136}$

Opponents encouraged the public to question the president's commitment human rights. Such contradictory arguments successfully convoluted the president's foreign policy vision. The Carter administration explained their human rights policy "approach was to be determined, principled, firm, and flexible," for instance. The two later characteristics appear to be in conflict. What exactly did the Carter administration mean by designing a policy that was both "firm and flexible"? It meant that they planned to be firm about their principles, yet flexible enough to respond appropriately to "constraints and opportunities," associated with foreign policy decision making. The administration recognized that human right policy was inherently complex and often presented contradictions. The administration contributed to this lack of clarity when they shifted away from making moral arguments in support of the Panama Canal treaties to making more pragmatic ones that emphasized the importance of security and the interests of the United States. While the pragmatic shift was meant to encourage Senate ratification of the treaties, it hindered the Carter administration's ability to communication its foreign policy principles. ${ }^{137}$

${ }^{136}$ Organization of American States, Inter-American Commission on Human Rights, "Report on the Situation of Human Rights in Panama," June, 22, 1978. Accessed online at http://www.cidh.org/countryrep/Panama78eng/TOC.htm

${ }^{137}$ Vance, Hard Choices, 44,442. 


\section{International Relations and U.S. Security}

Rather than accepting the Carter administration's premise that the treaties would improve international relations and allow the U.S. to once again take on a leadership role within the global community, treaty opponents argued that an external communist threat was a real concern in Panama. Exploiting Cold War fears, opponents described a "SovietCuban-Panamanian alliance," and labelled Torrijos a Marxist. What anti-treaty conservatives did not know, was that the Communist Party in Panama had been created and run by the CIA in an effort to infiltrate Moscow. ${ }^{138}$

Whether or not the U.S. was negotiating from a position of power was also a controversial debate point. Opponents argued the Panama Canal treaties represented "a giveaway" of the Panama Canal. In fact, the most ardent opponent of the treaties in the Senate, Sen. Strom Thurmond claimed the treaties allowed for "the greatest give-away since God gave man the world for his dominion." Republican Senator Jesse Helms of North Carolina argued that the treaties reflected American weakness, "which could literally destroy America.” Such arguments were designed to inspire fear. Treaty opponents exploited American insecurities borne out of the American military defeat in Vietnam, to encourage public opposition to the treaties. ${ }^{139}$

Conservative opponents viewed foreign policy using a Cold War paradigm, which reflected much different values than the Carter administration's foreign policy vision. While the president sought to increase international cooperation in an effort to take on a leadership role within the world, opponents argued that the treaties would threaten the

\footnotetext{
${ }^{138}$ Weiner, Legacy of Ashes, 321.

${ }^{139}$ Strom Thurmond quoted in Joseph Crespino, Strom Thurmond's America, (New York: , ): 260.
} 
prestige of the U.S. internationally, which would create a security risk. Conservatives valued maintaining a favorable balance of power vis-à-vis the Soviet Union, a goal that they believed would fail if the U.S. were to "giveaway" the Panama Canal. To conservative treaty opponents, the canal represented, not only American might, but also a strategic and tactical military asset. Treaty opponents argued the Panama treaties threatened American security, while President Carter viewed the treaties as essential to protecting American security interests and avoiding violence in Panama. Certainly both perspectives could not be correct. 


\section{CHAPTER V:}

\section{CONCLUSION}

Overall, the Carter administration's campaign to ratify the Panama Canal treaties was a success. The treaties were ratified by a single vote in the Senate and the Panama Canal was turned over to Panamanian control on the eve of the twenty-first century. Since, an expansion of the canal has been completed and the canal continues to be open to ships of all nations. Unfortunately, it is difficult to judge the success of President Carter's step towards greater international cooperation. Cyrus Vance blamed "structural and human constraints" for the Carter administration's unfulfilled vision. Perhaps if President Carter had not believed so ardently in the goodness and altruism of the American public, he could have anticipated some of these constraints and made greater efforts to counteract them. ${ }^{140}$

The Carter administration developed a coherent foreign policy vision based upon moral and political values. President Carter chose to pursue negotiation and Senate ratification of the Panama Canal treaties because the treaties aligned closely with his vision of international cooperation and justice in his pursuit of lasting global peace. Studying the Carter administration's foreign policy demonstrates the importance and power of historical argumentation and the diverse perspectives of public policy issues.

${ }^{140}$ Vance, Hard Choices, 13. 
The treaty debate demonstrated how policymakers reflect on history during their decision-making process and may even manipulate it to support their own political agenda. President Carter's understanding of history inspired him to pursue the Panama treaties. The president demonstrated an ability to learn from the past in an effort to correct an injustice. Even before he was elected president, Carter voiced his hope that "the lessons we have learned can be a basis for dramatic improvements in the prospects for world peace." The president believed human progress evolved consistently over time. He therefore sought to move forward by promoting positive change, which he believed demanded a greater respect for human rights and the maintenance of peace. ${ }^{141}$

Both President Carter and treaty opponents also made nostalgic arguments about the great American achievement of constructing the Panama Canal. Such arguments encouraged some patriotic Americans to insist upon the U.S. retaining control of the canal, whereas treaty proponents argued ratifying the treaties was the best way to protect the canal so the United States and countries of the world could continue using it. In the past the canal has also both benefitted and exploited the Panamanian people. One benefit Panamanian's received from their strained relationship with the U.S., was the backing of their independence. Once the canal was constructed, the benefits of the canal were not equally or equitably distributed between the U.S. and Panama.

Another historical argument focused on sovereignty. The Panama Canal either was or was not sovereign U.S. territory. Treaty opponents who argued that it was, misinterpreted the history of the original treaty agreement with Panama, yet their arguments in the public debate over the treaties were still powerful. The treaty debate

${ }^{141}$ Carter, New Approach to Foreign Policy, May 28, 1975, 4. 
demonstrates the political power of disinformation. It is important to recognize that even inaccurate statements can be political powerful and popular.

The Carter administration noted that "the lessons we draw from recent history is that public understanding and support are now vital to a successful foreign policy.” Despite this knowledge, the Carter administration failed to communicate the tenets of its morally inspired foreign policy vision. President Carter's foreign policy vision was never fulfilled. The president was unable to win public support for the Panama Canal treaties or many of his subsequent foreign policy initiatives. While an understanding history can aid in political decision-making, it certainly cannot predict the future. President Carter successfully developed a coherent foreign policy vision, but he was not able to consistently and effectively communicate his vision. The case of the Panama Canal treaties demonstrates that the Carter administration made politically pragmatic arguments in an effort to support the treaties, but in doing so also obscured its overarching vision. By choosing to frame the Panama Canal treaties pragmatically the Carter administration avoided inherent contradictions related to human rights policy. At the same time, choosing not to emphasize the moral foundations of its foreign policy may have raised doubts about the administration's commitment to these moral principles. ${ }^{142}$

Overall, President Carter's foreign policy differed greatly from the Cold War policy of his predecessors. Both polices however reflect elements of American exceptionalism. President Carter believed that the U.S. was uniquely qualified to provide moral leadership in an international system. He had faith that the American people would act morally an in accordance with American principles. In President Carter's 1978 State

${ }^{142}$ Carter, New Approach to Foreign Policy, May 28, 1975, 17, 4. 
of the Union Address, he spoke of such leadership stating, "we have placed American foreign policy on a new course consistent with the values and highest ideals of the American people." President Carter also believed the U.S. had a unique responsibility to take on a leadership role in the world. He explained that "no other country is as wellqualified as we to set an example," to countries around the world. He even believed the U.S. had "a special obligation to take on those moral duties which, when assumed, seem invariably to be in our own best interests." Despite the dramatic differences between Cold War policy and Carter's internationalized foreign policy, both reflect elements of American exceptionalism. While treaty opponents believed the U.S. was exceptionally capable of operating the canal, President Carter believed Americans were exceptionally ethical and would come to understand that turning the canal over to Panama was a moral imperative. $^{143}$

The Panama Canal treaties also demonstrate that bipartisanship on an incredibly controversial issue is possible. While politics have become increasingly polarized in the decades since the Panama Canal treaties were ratified, the successful ratification of the treaties inspire hope that politicians, such as Senator Howard Baker, Senator Frank Church, and President Jimmy Carter, can choose to support moral policies, despite potential political repercussions. While the Panama Canal treaties were not the only political issue that damaged future political prospects for these men, the issue was one where politicians were asked to do what was right rather than what was politically

${ }^{143}$ Jimmy Carter, "State of the Union Address," January 19, 1978, APP, http://www.presidency.ucsb.edu/ws/?pid=30867.; Jimmy Carter: "University of Notre Dame - Address at Commencement Exercises at the University," May 22, 1977. Online by Gerhard Peters and John T. Woolley, APP. http://www.presidency.ucsb.edu/ws/ ?pid=7552.; Jimmy Carter: "Inaugural Address," January 20, 1977, APP, http://www.presidency.ucsb.edu/ws/?pid=6575. 
expedient. President Carter only served one term as president, and scholars continue to criticize his effectiveness as a leader. Perhaps the example he set in campaigning for the ratification of the Panama Canal treaties may inspire future leaders to adhere to their principles rather than give in to public demands inspired by misinformation, self-interest, and fear.

While not often associated with President Carter's human rights policy, the Panama Canal treaties were congruous with the president's desire to protect these fundamental rights. The treaties demonstrate that many foreign policy issues can ultimately promote human rights. The need to protect these rights through cooperation, diplomacy, and the maintenance of peace is no less important today than it was during the canal debate. The canal treaties reflected a mutually beneficial solution to a problem that would promote human rights by providing economic benefits to Panama and setting a precedent for a cooperative relationships between a wealthy developed country and smaller developing one. The treaties have also successfully maintained the neutrality of the Panama Canal—demonstrating that the benefits of the treaties were truly global.

The Panama treaties also demonstrate the challenges of making moral political arguments. Since policy requires the consideration of a multitude of complex factors, including security, it is easy for the politicians to favor pragmatic arguments that may provide more immediate and measurable benefits than acting according to principle alone. An informed electorate that can make sound judgements even when presented with conflicting and emotional arguments is essential to developing productive democratic policies ideally reflect political values. 
Finally, recent history helps us understand President Carter's commitment to promoting peace. In a 2011 interview at the John F. Kennedy presidential library, he spoke of how proud he was that during his time as president the U.S. "never went to war. We never dropped a bomb. We never fired a bullet." President Carter judges his foreign policy success based on his ability to maintain peace. Carter's efforts were recognized in 2002 when he was awarded the Nobel Peace Prize "for his decades of untiring effort to find peaceful solutions to international conflicts, to advance democracy and human rights, and to promote economic and social development." In the years following his presidency, Carter remained committed to his vision's ultimate goal. ${ }^{144}$

The Panama Canal treaties were a policy initiative that clearly reflected the moral principles of President Carter's foreign policy and demonstrated the president's desire for the U.S. to take on a leadership role to establish a peaceful and just international system. The Panama Canal policy was aligned with the Carter's foreign policy principles of honesty, respect for sovereignty, peaceful international cooperation, and justice. While negotiating the treaties with a dictatorial regime seemed to contradict his emphasis on human rights, his desire to prevent potentially life-threatening conflict demonstrated his concern for the most vital of human rights. Overall, President Carter used the Panama Canal treaties to assert U.S. moral leadership within the international system and build stronger relationships with Latin American countries. The president pursued the Panama Canal treaties because he believed they allowed the U.S. to take on a role as a moral leader, correcting an unjust policy of the past and working cooperatively to establish an

${ }^{144}$ Quoted in Carol Cadwalladr "Jimmy Carter: 'We never dropped a bomb. We never fired a bullet. We never went to war."” The Observer, September 10, 2011.; "The Nobel Peace Prize for 2002 to Jimmy Carter_Press Release," Nobelprize.org. Nobel Media AB 2014. 
honest and fair agreement. Ratification of the treaties proved that "what is best and noblest in our national spirit will prevail," just as President Carter thought it would. In the future, we must demand that international leaders continue to work for the most fundamental facets of the Carter administration's foreign policy vision: the promotion of peace and respect for human rights throughout the world. ${ }^{145}$

${ }^{145}$ Carter, "Panama Canal Treaty Remarks During a Briefing on the Treaty" 


\section{BIBLIOGRAPHY}

\section{Primary Sources}

Bunker, Ellsworth. "Panama Canal Treaties: A Negotiator's Perspective." Speech, Des Moines, IA, January 26, 1978. Department of State, Bureau of Public Affairs, Office of Public Communication, 1978.

Carter, Jimmy. A Government as Good as Its People. New York: Simon and Schuster, 1977.

. Keeping Faith: Memoirs of a President. New York: Bantam Books, 1982.

. Public Papers of the Presidents of the United States: Jimmy Carter, 1977- 1981. 9 vols. Washington, DC: Government Printing Office, 1977-1984.

. White House Diary. New York: Farrar, Straus, and Giroux, 2010.

Crane, Philip M. Surrender in Panama: The Case against the Treaty. New York: Dale Books, 1978.

Falk, Richard A. "Panama Treaty Trap.” Foreign Policy 30 (Spring 1978): 68-82.

Jorden, William J. Panama Odyssey. Austin, TX: University of Texas Press, 1984.

Linowitz, Sol M. “The Panama Canal Treaties - in the National Interest.” Speech, Chicago, IL, October 18, 1977. Department of State, Bureau of Public Affairs, Office of Media Services, 1977. https://catalog.hathitrust.org/Record/100799454

Pippert, Wesley G. ed. The Spiritual Journey of Jimmy Carter In His Own Words. New York: Macmillan Publishing Company, 1978.

United States Department of State. Background Notes: Panama. (September 1977). https://babel.hathitrust.org/cgi/pt?id=txu.059173024472698;view=1up;seq=133

. Foreign Relations of the United States: Foundations 1977, edited by the Historical Office, vol. I. Washington, DC: U.S. Government Printing Office, 1977. 
U.S. National Archives. Panama Canal, the New Treaties, 11/1977. Washington, DC: Government Publications 1861-1992.

U.S. Senate. Committee on Foreign Relations. Panama Canal Treaties Hearings 1-5. Washington, DC: U.S. United States Government Printing Office, 1978.

.Committee on Foreign Relations. Senate Debate on the Panama Canal Treaties: A Compendium of Major Statements, Documents, Record Votes and Relevant Events. Washington, DC: U.S. United States Government Printing Office, Feb. 1979.

. Subcommittee on the Separation of Powers of the Committee on the Judiciary. Panama Canal Treaties. Washington, DC: United States Government Printing Office, 1977-1978.

. Subcommittee on the Separation of Powers of the Committee on the Judiciary. The Proposed Panama Canal Treaties: a Digest of Information. Washington, DC: United States Government Printing Office, Feb. 1978.

Vance, Cyrus. "The Panama Canal-Providing for the Future." Speech, New Orleans, LA, January 12, 1978. Department of State, Bureau of Public Affairs, Office of Media Services, 1978.

\section{Secondary Sources}

Clymer, Adam. Drawing the Line at the Big Ditch: The Panama Canal Treaties and the Rise of the Right. Lawrence, KS: University Press of Kansas, 2008.-

Domin, Gregory Paul. Jimmy Carter, Public Opinion, and the Search for Values, 19771981. Macon: Mercer University Press, 2003.

Eisenmann Jr. I. Roberto "Panama and the United States," Revista Harvard Review of Latin America XII, no. 3 (Spring 2013): 9-13.

Farnsworth, David N. and James W. McKenney. U.S.-Panama Relations, 1903-1978: A Study in Linkage Politics. Boulder: Westview Press, 1983.

Fenwick, Charles G. "Treaty Between the United States and Panama." World Affairs 118, no. 3 (Fall, 1955): 70-72.

Forsythe, David P. "Human Rights in U.S. Foreign Policy: Retrospect and Prospect," Political Science Quarterly 105, no. 3 (Autumn 1990): 435-454.

Glendon, Mary Ann. A World Made New: Eleanor Roosevelt and the Universal Declaration of Human Rights. New York: Random House, 2001. 
Hogan, Michael, J. The Panama Canal in American Politics: Domestic Advocacy and the Evolution of Policy. Carbondale, IL: Southern Illinois University Press, 1986.

Hollihan, Thomas A. "The Public Controversy Over the Panama Canal Treaties: An Analysis of American Foreign Policy Rhetoric," Western Journal of Speech Communication 50 (Fall 1986): 368-387.

Jordan, William J. “The Panama Treaty,” Diane B. Bendahmane, and John W. McDonald, Jr. Ed. Perspectives on Negotiation: Four Case Studies and Interpretations. Washington, DC: Center for the Study of Foreign Affairs, Foreign Service Institute, U.S. Dept. of State, 1986.

Katz, Andrew Z. "Public Opinion and the Contradictions of Jimmy Carter's Foreign Policy,” Presidential Studies Quarterly 30, no. 4 (Dec. 2000): 662-687.

Kaufman, Scott. Plans Unraveled: The Foreign Policy of the Carter Administration. DeKalb, IL: Northern Illinois University Press, 2008.

LaFeber, Walter. The Panama Canal: The Crisis in Historical Perspective. New York: Oxford University Press, 1978.

Long, Tom. Latin America Confronts the United States: Asymmetry and Influence. New York: Cambridge University Press, 2015.

McElroy, Robert W. Morality and American Foreign Policy: The Role of Ethics in International Affairs. Princeton: Princeton University Press, 1992.

Moffett III, George D. The Limits of Victory: The Ratification of the Panama Canal Treaties. Ithaca, NY: Cornell University Press, 1985.

Morris, Kenneth E. Jimmy Carter: American Moralist. Athens, GA: University of Georgia Press, 1996.

Pastor, Robert A. Exiting the Whirlpool: U.S. Foreign Policy Toward Latin America and the Caribbean. Boulder CO: Westview Press, 2001.

Renourard, Joe. Human Rights in American Foreign Policy: From the 1960s to the Soviet Collapse. Philadelphia, PA: University of Philadelphia Press, 2016.

Roscho, Bernard. "The Polls: Polling on Panama-Si: Don't Know: Hell, No!" The Public Opinion Quarterly 42, no. 4 (Winter 1978): 551-562.

Rozell, Mark J. "Carter Rehabilitated: What Caused the $39^{\text {th }}$ President's Press Transformation?" Presidential Studies Quarterly 23, no. 2 (Spring 1993): 317330. 
Sargent, Daniel. A Superpower Transformed: The Remaking of American Foreign Relation in the 1970s. New York: Oxford University Press, 2015.

Sikkink, Kathryn. Mixed Signals: U.S. Human Rights Policy and Latin America. Ithaca, NY: University of Cornell Press, 2004.

Skidmore, David. "Foreign Policy Interest Groups and Presidential Power: Jimmy Carter and the Battle over Ratification of the Panama Canal Treaties," Presidential Studies Quarterly 23, no. 3 (Summer 1993): 477-497.

. Reversing Course: Carter's Foreign Policy, Domestic Politics, and the Failure of Reform. Nashville, TN: Vanderbuilt University Press, 1996.

Smith, Craig Allen. "Leadership, Orientation, and Rhetorical Vision: Jimmy Carter, The 'New Right,' and the Panama Canal," Presidential Studies Quarterly 16, no. 2 (Spring 1986): 317-328.

Smith, Gaddis. Morality, Reason, and Power: American Diplomacy in the Carter Years. New York: Hill and Wang, 1986.

Strong, Robert A. Working in the World: Jimmy Carter and the Making of American Foreign Policy. Baton Rouge: Louisiana State University Press, 2000.

Sudol, Ronald A. "The Rhetoric of Strategic Retreat: Carter and the Panama Canal Debate.” Quarterly Journal of Speech 65 (1979): 379-391.

Zaretsky, Natasha. "Restraint or Retreat? The Debate over the Panama Canal Treaties and U.S. Nationalism after Vietnam," Diplomatic History 35, no. 3 (June 2011): 535-562. 